\title{
Control of tacky deposits on paper machines - A review
}

\author{
Martin A. Hubbe, Orlando J. Rojas, and Richard A. Venditti, North Carolina State University, Raleigh, NC, USA
}

KEYWORDS: Deposit control, Detackification, Fouling, Pitch, Stickies

SUMMARY: Wood-derived pitch and tacky materials of synthetic origin in recovered fiber streams often cause serious deposit problems on papermaking equipment. Ideally such materials would be completely removed in processes such as screening, cleaning, washing, or flotation de-inking. In practice, tacky materials that remain in the fiber furnish can build up within paper machine headboxes, forming fabrics, press sections, and dryer sections, reducing production efficiency. Product quality is likely to suffer, especially if deposited material ends up in the sheet. This review considers a variety of chemical additives that papermakers have used to combat deposit problems. The premise of this article is that knowledge of the chemistry and colloidal behavior of existing deposit-control agents can guide us in the selection, usage practices, and further development of strategies for the control of tacky deposits, especially in the case of pitch, adhesive-based stickies, and wax-like deposits.

ADDRESS OF THE AUTHORS: North Carolina State

University, Department of Wood and Paper Science, Box 8005, Raleigh, NC 27695-8005, USA.

Corresponding author: Martin Hubbe (hubbe@ncsu.edu)

A variety of tacky materials are present in papermaking water systems. These substances are brought into the process through many different sources and means, including the raw materials. Tacky materials may come from virgin wood pulp, recycled waste paper, as well as broke. (Back, Allen 2000; Dechandt et al. 2004). They can come from functional and control additives used in the pulp and paper mill, and also chemicals from recycled paper containing latex (from coated papers) (Laubach 1994), adhesives, waxes and other hot-melt materials (Patel, Banerjee 1999), and elastomers from pressure-sensitive labels (Doshi 1991; Capozzi, Rendé 1994; Douek et al. 1997). In most cases a given sample of deposit from a paper machine system contains a variety of tacky materials mixed together.

The deposition of organic substances is considered a major problem in multiple stages of pulp and paper processing. Some of the undesired effects involve increases in downtime, costs to replace paper machine clothing (forming fabrics, press and drying felts), more frequent paper breaks (and related cleanup downtime), reduction of product quality (fish eyes, pinholes and picking), reduced operational efficiency (e.g., in washing operations), and losses in productivity of converting and printing operations, etc.

Previous reviews have considered the nature of the tacky materials that are often found in analytical tests of deposits collected on the wetted surfaces of paper machines (Swanson, Cordingly 1956; Parmentier 1980a; Hassler 1988; Dreisbach, Michalopoulos 1989; Glazer 1991; Doshi 1991; Doshi 1992; Carré et al. 1998; Ling
1998; Back, Allen 2000). In this account we consider the fundamentals of the various treatments available to combat a diverse range of tacky deposits. A broad approach is used, since chemicals that are effective for combating one type of tacky material may or may not be effective for others.

Although there are some characteristic differences among the types of tacky materials found in papermaking systems, there also are some common features. For instance, wood pitch components, waxes, defoaming chemicals, and pressure-sensitive adhesives all tend to be relatively insoluble in water. Significant deposition problems typically involve temperatures that exceed the glass transition point of at least one component of the organic materials present (McLaren 1948; McLaren, Seiler 1949; Comyn 1997; Knubb, Zetter 2002). The glass transition point can be defined as the temperature at which a material transitions from a glassy form to a liquidlike or rubbery form. Finally, most serious problems with tacky deposits involve colloidal destabilization by multivalent cations, charge neutralization, or hydrodynamic shear. Particles also can be collected together by rising foam bubbles. Temperature changes can render the materials tackier and therefore more likely to form deposits. Effects of individual factors, as well as combinations of factors affecting the likelihood of deposit formation, have been considered by various authors (Allen, 1980; Dreisbach, Michalopoulos 1989; Carré et al. 1998; Back 2000).

The word "pitch" is often used to designate tacky materials derived from wood (Back, Allen 2000; Ekman, Holmbom 2000; Qin et al. 2004). The tendency of fatty and resin acids to form films and micelles have been elucidated by studies of mono- and multi-molecular films (Swanson, Cordingly 1956; Neuman 1975; Neuman 1976; Neuman, Swanson 1980). So-called "stickies" (Doshi 1991; Capozzi, Rendé 1994; Venditti et al. 1998, 2000), which are of particular concern to users of recycled paper, are most often the result of synthetic polymers used in pressure-sensitive label adhesives.

For various reasons tacky deposits have tended to become an increasing problem in paper machine systems. Trends towards a reduction of the amount of fresh water employed in the papermaking process have generally increased the levels of colloidal substances in paper machine systems. Colloidal substances can build up to high levels in cases where the retention efficiency of those materials on fiber surfaces is relatively low (Pietschker 1996; Lindholm 1998; Huhtamäki 2003). Increased recycling of paper, as well as evolving trends in printing and adhesive use have tended to increase the levels and diversity of tacky materials entering the system. Ideally, these materials ought to be removed in various separation processes associated with recycling the secondary fibers (Hodgson 1997). 
Though the present review focuses on tacky materials, deposits of such materials often occur in combination with other kinds of organic and inorganic scales or deposits. For instance, some deposits may be mainly caused by slime bacteria or fungi (Nahley 1995; Edwards 1996; Anstey et al. 1998; Simons et al. 2004). Such deposits often can be mitigated by use of organic biocides, oxidizing agents, surfactants, and enzymes. In addition, tacky deposits may be accompanied by precipitation of inorganic scale (Amjad 1995; Potter 1996; Amjad et al. 2000; Wang 2002).

\section{Summary of types of additives effective against deposits}

Chemical antidotes to combat tacky deposits on paper machines are, if anything, even more diverse than the deposits themselves. Later sections of this article focus on different classes of deposit-control treatments. These include adsorbent materials, multivalent cations, polyelectrolytes of various degrees of charge density and hydrophilic or lipophilic character, inorganic dispersants, surfactants, solvents, biocides, and enzymes. It is common for two or more such approaches to be applied simultaneously, often at different points in the papermaking process. Overall, there is continual development of anti-deposit treatments, usually with a goal of decreasing the cost of first-quality paper production. Some newer developments have been motivated by a desire to minimize various environmental impacts (Anastas et al. 2001; Allen 2002).

\section{Removal during repulping and de-inking}

To place the present review in context, it is usually recommended to deal with tacky materials in the furnish during pulping, rather than during papermaking. By removing tacky materials earlier in the process, the vulnerable and somewhat delicate parts of the paper machine system can be spared. Removal technologies, including screening, cleaning, washing, and flotation have been reviewed by others (Allen 1980; Moss 1997; Hodgson 1997). Tacky materials are also often removed during de-inking operations (Williams 1987; Borchardt 1992).

Removal of tacky materials early in the recycling process also is recommended because subsequent screening and pumping operations can break down tacky particles into smaller sizes, increasing the difficulty in removal. As an example, it has been shown that pressure screening, considered the most effective method to remove pressure sensitive adhesive (PSA) particles, can under common conditions generate three times the number of PSA particles than entering the operation (Lucas et al. 2001a,b). As a consequence, the resulting particles have an average size of about one-third that of the feed.

Finally, if removal measures are inadequate, on-machine chemical treatments for tacky materials are often accompanied by mechanical methods. One of the most popular of these is the placement of doctor blades on dryer cylinders to continuously remove tacky materials (Brink 1997).

\section{Some leading causes of deposit formation}

Because the causes of deposits on papermaking equipment are linked to the nature of the tacky materials, we first discuss briefly the chemical characteristics of the most important components in these substances. Wood itself contains a large variety of resinous substances. The chemical nature and concentration of these resinous substances depends heavily on the type of fiber (softwood, hardwood, and non-woody plants), the specific specie, and even the season of harvesting. Table 1 provides a simplified comparison of the nature and concentration of resin compounds in softwoods and hardwoods (Ekman, Holmbom 2000).

Table 1. Major wood resin compounds in pine softwood and aspen hardwood (Ekman, Holmbom 2000).

\begin{tabular}{lcc}
\hline & \multicolumn{2}{c}{$\%$ based on dry wood } \\
Component & Pine (softwood) & Aspen (hardwood) \\
\hline Fatty acids & 0.02 & 0.09 \\
Resin acids & 0.32 & \\
Sterols & 0.07 & 0.06 \\
Steryl esters & 0.13 & 0.64 \\
Neutral diterpenoids & - & 0.01 \\
Waxes & - & 0.01 \\
Mono-/di-/triglycerides & 2.57 & 1.55 \\
Total & 3.10 & 2.36 \\
\hline
\end{tabular}

Virgin fibers are typically the main source of natural and modified resinous materials present in papermaking process streams. Vercoe et al. (2005) showed that the deposition tendency of pitch droplets composed of triglycerides and resin acids was strongly influenced by their relative solubility in water under ideal laboratory conditions. Deposition increased with increasing hydrophobic character. Surprisingly, the effects of unsaturated bonds within the fatty acid groups had a greater influence than the molecular masses of the tacky materials under the conditions of study.

Recycled fiber brings additional contaminants, including pressure-sensitive adhesives, hot melts, waxes, and latexes. Any dispersants, minerals, defoamers, etc., which are added to the system during the papermaking process, augment the chemical variety and complexity of the tacky substances to be dealt with. It would be an impossible task to give a full account of all components present in the water systems in a papermaking process. A more generic approach for the definition and characterization of tacky substances relies in their thermodynamic nature (e.g. surface energies), including the way various components interact with other substances (i.e. colloidal stabilization or destabilization).

\section{Dispersed phases, thermodynamic instability}

The underlying cause of most tacky deposits in paper mill systems can be described as thermodynamic instability of various materials in the water phase (Derjaguin, Landau 1941; Verwey, Overbeek 1948; Hiemenz, Rajagopalan 1997). At the limit of long equilibration times, thermodynamic processes favor the adhesion and 
mixing of materials that have similar solubility characteristics. Solubility of a material often can be predicted based on components of interactive energy, including dispersion force (van der Waals) and acid-base components, as well as hydrogen bonding characteristics (Comyn 1997; Barton 1982). Similar considerations govern whether liquid droplets of tacky materials will or will not spread onto solid surfaces with which they may collide (Voue et al. 1998). The law of thermodynamics favors coalescence of tacky materials and their separation from the aqueous phase. Fortunately, within the processes of pulping and papermaking there are many potential opportunities to influence the rates and manner of this phase separation. For instance, by various chemical treatments, deposit formation may be greatly slowed, or the offending material may be encouraged to precipitate onto fibers or absorbent materials,rather than onto papermaking equipment (Dreisbach, Michalopoulos 1989).

To understand what causes tacky materials to come out of suspension and form deposits at significant rates, one needs to consider ways in which tacky particles may be stabilized in a suspension. The two most important mechanisms to inhibit deposition or agglomeration are electrostatic repulsion and steric stabilization. Our understanding of electrostatic forces in stabilization against coagulation has progressed rapidly, with major theoretical advances starting in the 1940's (Derjaguin, Landau 1941; Verwey, Overbeek 1948). It has been shown that the buildup of counter-ions, present in the so-called diffuse layer adjacent to like-charged surfaces, tends to slow down their rates of collision, even in the presence of Brownian motion or convective flow (Hogg et al. 1966). As we will see, charge stabilization, acting alone, tends to be vulnerable to various destabilizing factors present in industrial processes.

By contrast, steric stabilization involves the adsorption of relatively long-chain hydrophilic groups, which may be either in the form of polymers or surface-active agents. Close approach of surfaces coated by such hydrophilic layers involves an energetically unfavorable compression of the molecular chains extending outwards from each surface (Napper 1977; Rojas et al. 1998; Morra 2000; Nnebe et al. 2004; Stubenrauch et al. 2004a,b). Steric stabilization has been demonstrated in the case of wood pitch in the presence of hemicellulose components (Clas et al. 1993). The dependency of pitch particle stability on steric stabilization also has been demonstrated by breaking down polysaccharide layers with an enzyme (Sundberg et al. 1994a). Enzymatic treatment rendered the pitch particles susceptible to coagulation at a much lower dosage of cationic polymer. Pressure-sensitive adhesives (Huo et al. 1999, 2001, 2002) and some toner particles (Snyder, Berg 1994; Zeng et al. 1999, 2001) have been shown to be sterically stabilized by starch.

The word "tack" can be defined as the tendency of a material to adhere following such a collision. A substance suspended in water can exhibit tackiness only if the molecules facing the water are mobile; in other words the material must be above its glass transition temperature, $T_{\mathrm{g}}$ (McLaren 1948; Comyn 1997). Tackiness is difficult to predict, however, since the value of $T_{\mathrm{g}}$ can be reduced by water (Back and Salmén 1982; Salmén et al. 1985; Olsson, Salmén 2004), or other materials such as the surfactants used in dissolved air flotation (Elsby 1986). Simply noting the $T_{\mathrm{g}}$ of the pure component materials is not an adequate predictor of tack in a complex system. Reduced tackiness may be observed if the temperature becomes high enough to substantially reduce the viscosity of the material (McLaren, Seiler 1949). This general type of temperature-dependency has been found to govern the deposition tendency of alkylketene dimer (AKD) sizing agent (Knubb, Zetter 2002), as well as latex products used in coating that can return to the paper machine as "white pitch" from coated broke (Vähäsalo, Holmbom 2005).

\section{Brownian motion and flow as mechanisms of destabilization}

Starting with the work of Smoluchowski (1903, 1917; Hiemenz, Rajagopalan 1997) it has been understood that tiny particles in suspension experience random, jerky motions related to their thermal kinetic energy. The immediate cause of each change in direction can be attributed to a collision between the particle and an adjacent molecule in the solution. Brownian motion, as described, is a primary cause of diffusion of molecules and small particles, especially in the absence of flow. Brownian motion can explain, for instance, why it is possible for tacky particles to collide with each other and grow into larger agglomerates even in stagnant tanks.

Rates of Brownian collision among spherical particles or between spheres and flat substrates can be accurately predicted in certain situations. For instance, calculations can be carried out if known electrostatic forces of repulsion are acting between the surfaces. Rates of coagulation have been found to depend on the height of a barrier of free energy that opposes collision between the suspended particles or droplets when the surfaces have the same sign of electrical charge (Derjaguin, Landau 1941; Verwey, Overbeek 1948; Hogg et al. 1966; Hiemenz, Rajagopalan 1997). Calculation is especially simple in cases where there is no net inter-particle repulsive force, leading to the so-called "rapid coagulation" considered by Smoluchowski (1903, 1917). As will be discussed later, various chemical additives can either neutralize or screen the effects of the electrostatic repulsive forces, leading to coagulation rates that can be calculated based on the number of particles, their sizes, and their shapes. The following equation predicts the initial rate of doublet formation in a suspension of equal spheres in the absence of flow, under the assumption that the spheres attract each other once they approach within several nm of each other (Hiemenz, Rajagopalan 1997),

$$
\text { Rate }=-[8 k \mathrm{~T} /(3 \eta)] \mathrm{N}_{\mathrm{o}}^{2}
$$

In $E q$ [1] $k$ is the Boltzmann constant, $T$ is absolute temperature, $\eta$ is the dynamic viscosity, and $N_{\mathrm{o}}$ is the initial number concentration of the particles in suspension.

Flow conditions can greatly accelerate the deposition of tacky materials, especially when the particles are 
relatively large. Estimates of the hydrodynamic shear stress at different locations within a typical paper machine system generally lie within the range 10 to 20,000 Pa (Tam Doo et al. 1984). Eq [2] describes rates of inter-particle sticking collisions in turbulent flow (Saffman, Turner 1956; Swerin, Ödberg 1997; Huang, Pan 2002):

$$
\text { Rate }=4 / 3 \alpha(\varepsilon / v)^{0.5}\left(a_{1}+a_{2}\right)^{3} N_{\mathrm{o}}^{2}
$$

where $\alpha$ is a coefficient giving the probability that a given collision results in sticking, $\varepsilon$ is the rate of energy dissipation in turbulent flow, $v$ is the kinematic viscosity, and $a_{1}$ is the radius of one of the colliding particles, treated as a sphere.

Although $E q$ [2] can provide reasonable estimates of inter-particle collisions in practical applications, hydrodynamic effects can greatly influence the probability of collisions of materials in flowing suspensions. As noted by van de Ven and Mason (1981), suspended materials exposed to simple shear flow tend to avoid each other, resulting in collision rates far lower than those predicted based on the undisturbed streamlines of flow. In particular, hydrodynamic models predict that very small particles, e.g. pitch in a flowing suspension, are relatively unlikely to impinge upon the main surface of a fiber. Rather, a much higher relative rate of collision would be expected when streamlines of flow bring a tiny particle towards a similarly-sized fibril structure at a fiber surface. Early evidence of preferential deposition of fine particles onto fibrils (Haslam, Steele 1936) has recently been confirmed by high-resolution imaging of macromolecular events occurring during the formation of paper (McNeal et al. 2005).

One of the most vexing problems with sticky materials in papermaking furnish is that the same hydrodynamic shear forces that can accelerate deposit problems sometimes have the opposite effect of tearing the tacky material into finely divided fragments or droplets that are very difficult to retain during the formation of paper. So-called microstickies (Gruber et al. 1998; Menke 1998; Huo et al. 2001) appear to form during intense or prolonged agitation of stock. Stickies also have a tendency to extrude themselves through screening devices, especially under industrial conditions involving elevated temperatures and intense pressures (Lucas et al. 2001; Flanagan 2002; Venditti et al. 2004).

\section{Gravity-induced destabilization}

Gravity can act in various ways to destabilize suspensions of pitchy or sticky particles. Velocities of sedimentation or creaming of individual, spherical particles are given by the Stokes-Einstein equation,

$$
\mathrm{V}=\operatorname{Sqrt}\left[8 g\left(\rho_{\mathrm{s}}-\rho_{\mathrm{f}}\right) a /\left(3 \mathrm{C}_{\mathrm{d}} \rho_{\mathrm{f}}\right)\right]
$$

where $g$ is the gravitational (or other) acceleration, $\rho_{\mathrm{s}}$ is the density of the solid, $\rho_{\mathrm{f}}$ is the density of the fluid, $a$ is the particle radius, and $C_{d}$ is the displacement factor, which is equal to 1 in the case of a sphere (Einstein 1956). It follows from this equation that rates of gravi- tational separation are directly proportional to the difference in densities of the two phases. The rates of settling or creaming of spherical particles also are predicted to be proportional to the radius. In the case of liquid droplets the rates of gravitational separation can be greatly increased by coalescence, increasing the value of the effective radius. The situation is admittedly more complex in the case of solid particles, though it is often satisfactory to define effective values of the radius and density terms in $E q$ [3]. Similar considerations govern the rising of bubbles, as in the case of flotation de-inking (Heindel 1999).

\section{Chemically induced destabilization}

Suspensions of resinous materials that are stabilized by charge repulsion alone often can be coagulated by increases in electrolyte content or water hardness (Farley 1977; Allen 1980; Hassler 1988; Abraham 1998; Pelton, Lawrence 1991; Clas et al. 1993; Huo et al. 2001) or by decreases in $\mathrm{pH}$ (Sihvonen et al. 1998). Complexation between the hardness ions and particles of pitch or stickies appears to lessen the negative potential at the particle surfaces. Hardness ions also can make materials substantially tackier, as in the case of hydrolyzed alkenylsuccinic anhydride (ASA) sizing agent (Scalfarotto 1985). Decreased $\mathrm{pH}$, within the range 7 to about 3, tends to protonate carboxyl groups, which are often the main contribution to negative charge of pitch and other tacky materials in the wet end of a paper machine. Hardness ions also can bring about destabilization of wood pitch, especially in cases where the lipophilic droplets have a negative charge due to the presence of fatty acid salts (Otero et al. 2000; Qin et al. 2004).

More complete neutralization, and even reversal of negative charges of tacky materials can be achieved by addition of multivalent cationic materials such as aluminum ionic species (Matijeviç, Stryker 1966; Ormerod, Hipolit 1987; Hassler 1988; Bottéro, Fiessinger 1989) or strongly cationic polyelectrolytes (Winter et al. 1992; Shetty et al. 1994; Richardson 1995; Colman et al. 1996; Carré et al. 1998; Baumann et al. 2002). Though it might seem elementary to bring about particle coagulation by such treatments, the results can be difficult to predict. As will be shown later, treatments with highly cationic materials can have various different effects on the tackiness of the resinous material in question (Ormerod, Hipolit 1987; Hassler 1988; Dreisbach, Michalopoulos 1989; Carré et al. 1998). Also, if the level of treatment is sufficient to reverse the charge of the system, then the suspended particles can be stabilized by double-layer repulsion originated from strong net positive charges of the treated surfaces.

\section{Scale and inorganic deposits}

Deposits of tacky materials sometimes can occur in association with scale deposits. By definition, scale results from the chemical precipitation of inorganic compounds in locations where the solubility product between the constituent ions are exceeded. Common examples of scale-forming compounds, observed in papermaking applications, include silicates (Saasta- 
moinen et al. 1995; Froass et al. 1997), barium sulfate (Rudie 2000), and aluminum hydroxide (Potter 1996). The hardness ions $\mathrm{Ca}^{2+}$ and $\mathrm{Mg}^{2+}$ can interact with anionic species such as carbonate and oxalates, forming insoluble precipitates that tend to be particularly troubling in papermaking applications. The deposit-control strategies to be discussed later in this article are seldom effective in combating scale problems. Rather, most scale problems require either efforts to reduce the aqueous concentration of at least one of the common ions of the depositing inorganic material, or addition of an ionic substance capable of changing the adhesiveness or cohesiveness of the deposited material. Scale inhibitors are commonly used, including polyphosphates, hydroxyl ethyl diphosphate (HEDP), poly(acrylic acids), and others.

\section{Source-oriented solutions to tacky deposits}

Source-oriented approaches can minimize tacky deposits at vulnerable parts of the papermaking process. In particular, deposits that build up within the headbox, on forming fabrics, in the press section, and on dryer cans have the potential to hurt both the efficiency of the processes and product quality in papermaking.

Deposit problems related to wood pitch often can be minimized by allowing incoming wood chips to stand in piles for several days or weeks before use (Blazey et al. 2002). Benefits of chip aging usually are explained in terms of hydrolysis of the triglycerides component of the extractives. Oxidation, which can occur during extended aging, increases the hydrophilic character of the wood resins and provides a means by which they can interact more strongly with soluble aluminum products, which are often used in pitch-control strategies (see later). Oligomerization among unsaturated hydrocarbon groups within resin acid species has a tendency to increase the glass transition temperature, sometimes reducing tackiness in subsequent operations, depending on the temperature (Back, Allen 2000).

In the case of recovered fibers, conditions of screening and other unit operations associated with pulping, cleaning, or de-inking can be optimized for efficient removal of sticky materials (Moss 1997; Hodgson 1997). Recent work showed that conditions of pressure drop and operating temperature during commercial-scale screening operations can tend to be too harsh for efficient exclusion of pressure-sensitive adhesives (Lucas et al. 2001; Venditti et al. 2004). It follows that modified operating conditions and/or equipment design have the potential to reduce the amounts of sticky materials that reach later papermaking operations. By contrast, application of excessive levels of hydrodynamic shear during repulping can separate adhesive material into very small particles, known as micro-stickies (Gruber et al. 1998; Menke 1998; Huo et al. 2001). Though many problems related to removal of stickies appear to be solvable by known separation methods, future papermakers can expect to face an increasingly bewildering array of new or modified sticky materials in recovered fiber supplies where the combination of mechanical and chemical approaches are potentially more effective.

\section{Deposit-control agents for tacky substances}

Within the paper machine system a variety of strategies have been used to reduce or eliminate problems resulting from deposition of tacky materials (Braitberg 1966; Parmentier 1980a; Hassler 1988; Dreisbach, Michalopoulos 1989; Glazer 1991; Doshi 1991; Doshi 1992; Fogarty 1993; Robertson, Taylor 1994; Blankenburg, Schulte 1996; Colman et al. 1996; Gill 1996; Back, Allen 2000; Dechandt et al. 2004). The mechanisms by which such strategies function are not completely understood. However, it still makes sense to categorize the various approaches for deposit control as alternatively involving adsorbents, multivalent inorganic cations, polyelectrolytes, nonionic dissolved polymers such as polyvinyl alcohol and mannans, dispersants, surfactants, solvents, enzymes, and also mechanical treatments.

\section{Adsorbent materials}

Talc has been the benchmark against which many other existing or prospective deposit-control treatments are often ranked. Talc is a natural magnesium silicate having a platy structure, non-abrasive nature (if pure), and a high affinity towards oleophilic materials (Doshi 1992). Talc has two surfaces, an oil-loving (lipophilic) face, formed by cleavage of the layers and consisting of neutral oxygen atoms, and hydrophilic edges. As in the case of "talcum powder," which is used for infant care, etc., talc's oilloving character can cause it to form clumps on the surface of water, rather than becoming dispersed. Nevertheless, application of sufficient agitation, especially in the presence of a dispersant (see later), can result in a fine particulate dispersion. Talc products used for deposit control are generally of the "fine" variety, having particle sizes (equivalent spherical diameters) in the range of 0.5 to about $20 \mu \mathrm{m}$, based on sedimentation velocity tests.

Dispersed talc can be applied at various points in the papermaking process, starting with the pulp mill or deinking plant, and continuing up to the thin-stock recirculation section of the paper machine. Relatively early addition of talc to the process is favored, especially in cases where a high proportion of the tacky materials enter from one or more identifiable thick-stock streams or other sources. For example, talc is sometimes added to de-inked pulp or coated broke. Early collection of tacky particles onto solid surfaces in suspension helps to minimize the likelihood that they agglomerate together, forming deposits large enough to hurt the appearance of the resulting paper. In general, the target material(s) need to already be tacky under the process conditions of papermaking, not just under the elevated temperatures of drying, in order for talc addition to be effective (Doshi 1992). It is recommended to use an effective retention aid system so that talc laden with tacky substances becomes purged from the recirculating process water of the paper machine. Very small tacky particles incorporated into the paper product, in conjunction with talc, seldom cause concerns to the end-user. Finally, the main advantage of using talc is its low cost and ease of use compared to some of the alternatives. 
In the case of wood resins, various evidence favors an "adsorbent" model to describe talc's function (Gill 1974; Mosbye et al. 2003). This model is illustrated schematically in Fig 1 for the case of very small tacky materials. In support of this model, addition of talc has been found to substantially reduce the number concentration of pitch particles visible in paper machine process water, based on microscopic counts (Parmentier 1980b). Allen (1980) observed as many as 14 pitch particles adsorbing onto a single particle of talc. A substantial decrease in overall tackiness is expected whenever organophilic materials become sandwiched between two plates of talc (Gill 1974). Addition of low amounts of talc often can result in an increase in the net mass of deposited material (Hassler 1988), giving further evidence to the high affinity between the materials. By contrast, addition of $0.2 \%$ talc, on a volume basis, was found to reduce the overall tackiness of wood pitch. For de-inking applications it has been suggested to add 0.6 to $1.9 \%$ of talc, based on oven-dry fiber mass (Williams 1987).

In addition to the adsorption model, just mentioned, it also has been proposed that talc in paper machine systems can change the rheological characteristics of tacky materials, rendering them non-tacky (Allen et al. 1993). Chewing gum is a familiar demonstration of this phenomenon; if no talc had been used in its formulation, gum would stick excessively to the teeth. Talc also appears to be able to delaminate upon application of sufficient shear. Presumably such delamination, if it occurs within an agglomerated mass of talc and tacky materials, would tend to reduce the dimensions of objectionable materials (Allen et al. 1993). In other cases, talc has been described as having poor resistance to hydrodynamic shear (Fogarty 1993), making it essential to verify each application strategy under commercial conditions.

In addition to the model shown in Fig 1, relatively small talc particles can attach to larger adhesive particles such as shown in Fig 2. The coating of talc on the large sticky particle renders the overall surface less tacky, discouraging deposition on machinery and paper machine clothing (Gill 1974; Allen 1980; Doshi 1992; Shetty et al. 1994; Huo et al. 1999; Huo 2002).

Direct evidence of talc particle adhesion to the surface of tacky particles was obtained during a thesis project related to recycling of paper that contains adhesives of the type used in pressure-sensitive labels (Huo 2002). Fig 3 clearly shows talc particles adsorbed at the surface of stickies following agitation of the elastomeric material in the presence of a dilute dispersion of talc.

Unexpected support for the adsorption mechanism of detackification was obtained during a study of the effects of recycling of release liners along with pressure sensitive adhesives (Venditti et al. 2000). It was found that the presence of release liner material during recycling resulted in a smaller average size of the stickies. As shown in Fig 4, small flakes of release liner tended to cover much of the exposed surfaces of the stickie material, making it less likely that the particles will collide and stick together.

Bentonite is a so-called "swelling clay," the principal mineral component of which is montmorillonite. In

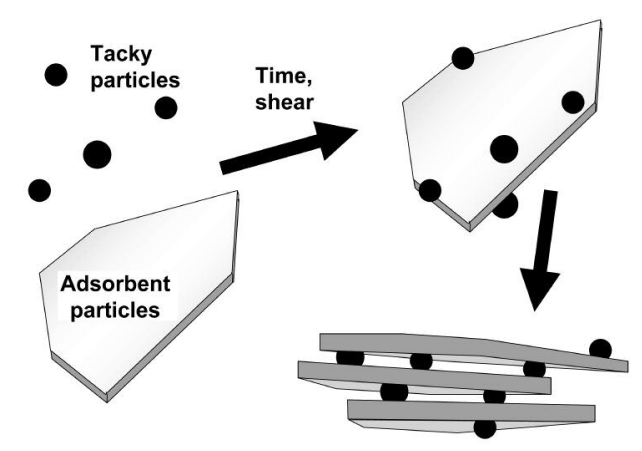

Fig 1. Model of talc as an adsorbent and detackifier.

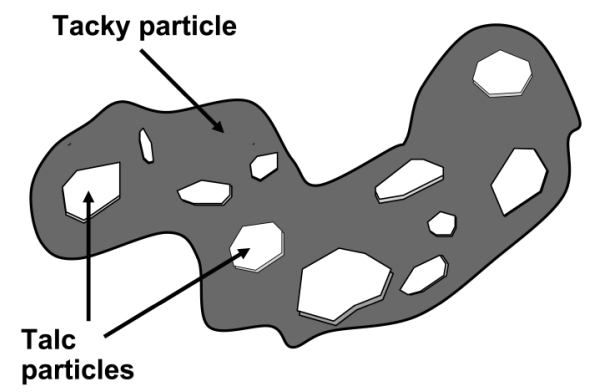

Fig 2. Model of talc adsorbing to the surface of a large tacky particle.
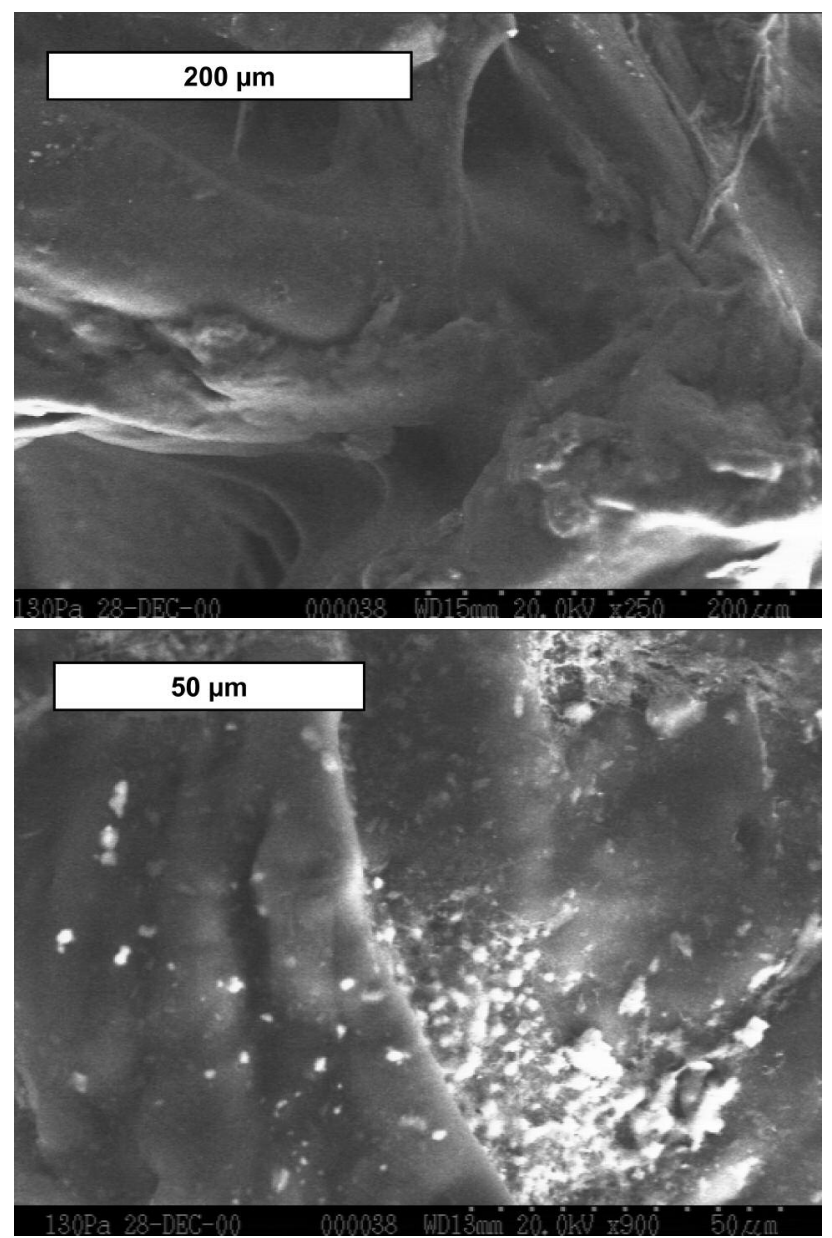

Fig 3. Micrographs of particles of elastomeric resin (stickies) agitated in the absence (top) and in the presence (bottom) of talc particles (Huo 2002).

contrast to talc, bentonite is more water-loving. Also, in contrast to talc, montmorillonite is capable of exfoliating much more easily into molecularly thin plates (Knudson 1993; Rodriguez 2005). Montmorillonite's physical properties are profoundly affected by the mineral's ionic 

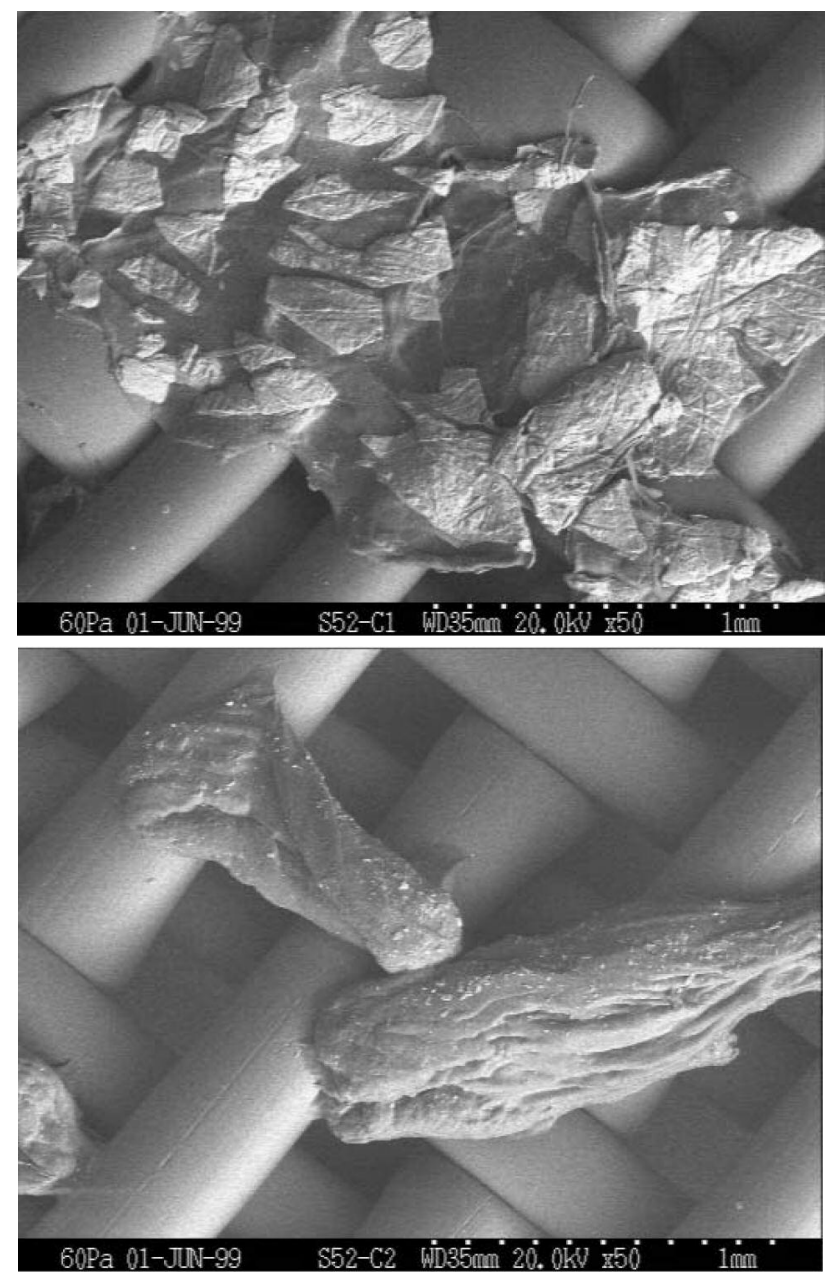

Fig 4. SEM picture of adhesive pulped in the presence of release liner (top) and without release liner (bottom) (Vendetti et al. 2000).

environment. Natural deposits usually are rich in alkaline earth cations, and in this form the solids show only moderate tendency to swell in water. Ion exchange, by treatment with $\mathrm{NaOH}$ or $\mathrm{KOH}$, together with the application of hydrodynamic shear, causes montmorillonite to exfoliate substantially into its component platelets.

Compared to talc, montmorillonite has a much stronger interaction with cationic polymers (Boardman, 1996; Rojas, 2002). Such interactions are well demonstrated by the use of bentonite products as agents of retention and dewatering. In such applications bentonite products are used in conjunction with cationic acrylamide retention aids (Hubbe 2005; Rodriguez 2005). A synergistic effect has been observed for pitch adsorption, when using bentonite products in sequence with a highly charged cationic polyelectrolyte (Derrick 1994; Boardman 1996).

Kaolin clay, though it usually is employed as an ordinary filler material in paper, also can take on the role of pitch adsorbent under special circumstances. Ordinary hydrous kaolin (Van Olphen 1991) would be expected to be too water-loving to be highly active in such a role. However, clay's ability to take up tacky materials can be greatly increased by pre-adsorbing positively charged polymers (Lamar et al., 1990; Curtis et al. 1995) or aluminum ionic species (Hyder et al. 1991; Carter, Hyder 1993; Harrison, et al. 1996). A similar polymeric pre-treatment strategy also has been applied to zeolites to achieve greater ability to remove wood resins from paper machine white waters (Bouffard and Duff 1999). A practice of treating minerals with cationic surfactant for such purposes has been criticized, since surfactants can desorb from a mineral after addition to a paper machine system (Carter, Hyder 1993).

Inorganic minerals having positively charged surfaces sometimes have been used for collection of tacky materials in papermaking systems. In the distant past it was sometimes recommended to use asbestos for this purpose (Woolery 1965). Apparently the naturally cationic nature of this material was helpful in binding the predominantly negatively charged colloidal materials found in paper machine systems. The fibrous nature of asbestos would be expected to favor its efficient retention in the paper web, removing the objectionable substances from the process. Colloidal alumina, produced in a precipitation reaction, was found to have similar capability (Braitberg 1966). Such materials have long since been discontinued from papermaking applications due to concerns about respiratory health.

More recently it has been found that precipitated calcium carbonate (PCC) can be effective for adsorption of tacky materials (Whiting 1997). Though the positive surface charge of pure PCC is relatively weak, charge still can be expected to play a role in its adsorption of oleophilic colloids from papermaking processes. PCC is frequently added in relatively huge quantities, often 10$30 \%$ based on the dry weight of the paper product. The composite structure of the popular scalenohedral (rosette) form of PCC provides internal voids that would be expected to be effective for holding onto colloidal particles so that they can be purged harmlessly from the process.

Synthetic, organic fibers also have been found to be effective for removing tacky materials from paper machine process water (Wade 1987). Polypropylene fibers have an oleophilic surface and can be efficiently retained during the formation of paper.

\section{Multi-valent inorganic cations and detackification}

The use of either aluminum sulfate (papermaker's alum) or poly-aluminum chloride (PAC) as a component in antideposit treatment programs is well known, especially for systems that contain wood resins (Allen 1980; Dreisbach, Michalopoulos 1989; Glazer 1991). In principle it is often possible to bring about the agglomeration or deposition of suspended tacky materials by neutralization of their surface charges (Verwey, Overbeek 1948; Hogg et al. 1966). Aluminum compounds are expected to be especially effective for such purposes due to their high positive valencies (Matijeviç, Stryker 1966; Strazdins 1989; Bottéro, Fiessinger 1989). Ideally, agglomeration is carried out in the presence of either fibers or another suitable adsorbent material (see previous sections), so that the tacky materials become collected on their surfaces. If not, addition of coagulating chemicals may merely accelerate self-agglomeration and/or deposition of the tacky materials onto the wetted surfaces of papermaking equipment.

Although charge neutralization can explain many of the effects of aluminum sulfate and related coagulants, it 
is also important to consider charge-reversal phenomena. Multivalent ions of aluminum tend to adsorb strongly onto negatively charged surfaces, giving them a positive net charge if the dosage is high enough (Matijeviç, Stryker 1966). Examples of this phenomenon already have been cited, involving pretreatment of clays with aluminum salts to achieve a positive surface charge (Lamar et al. 1990; Hyder et al. 1991; Carter, Hyder 1993; Curtis et al. 1995; Harrison et al. 1996). Attraction of tacky materials to the adsorbent surfaces is increased, since the tacky materials present in paper machine systems are usually anionic.

In like manner, adsorption of aluminum-based material onto resinous or sticky materials can be expected to make the surfaces cationic, such that they have a greater tendency to be retained onto the generally negative surfaces of cellulosic fibers and fines. Another consequence of aluminum ions' adsorption onto resinous materials is a more water-loving character. It follows that a tacky material coated with a hydrophilic layer of aluminum hydroxide and related compounds would be less likely to adhere and coalesce with another similar surface in the suspension.

Though aluminum sulfate (alum) can be an especially cost-effective coagulant under ideal, acidic $\mathrm{pH}$ conditions, there are many situations where greater coagulating efficiency can be achieved with partially hydroxylated formulations based on aluminum chloride (Strazdins 1989). Such products go by the names of poly-aluminum chloride (PAC), and aluminum hydroxychloride, etc., and they contain oligomeric ionic species. The seven-valent cation $\left[\mathrm{AlO}_{4} \mathrm{Al}_{12}(\mathrm{OH})_{4}\left(\mathrm{H}_{2} \mathrm{O}\right)_{12}\right]^{7+}$ appears to be especially prominent in many products of this type (Bottero et al. 1980; Bottéro, Fiessinger 1989; Crawford and Flood 1989). Such ions appear to be the main chemical species involved with soluble aluminum product's interactions with anionic polymers (Chen et al. 2004). The use of an aluminum chloride-based product for pretreatment of clay was noted earlier (Harrison et al. 1996). PAC products also were found to perform very well as part of "passivation" treatments, which will be discussed later (Colman et al. 1996).

Work by Dreisbach and Michalopoulos (1989) suggested that alum can render the surfaces of pitch particles more rigid. This effect can be considered as a form of detackification. Similar effects have been observed in studies of monomolecular layers of insoluble fatty acid salt films spread at the aqueous interface (Swanson, Cordingly 1956). Alum treatment converts such films from liquid-like to solid-like in their two-dimensional phase behavior.

Similar to aluminum compounds in terms of having a small, high-valence, hydroxylated, positive ions, zirconium compounds also are useful as detackifiers. Zirconium products have been found to be effective in reducing the tack of various polymer-based adhesives, either alone (Goldberg 1987; Whiting 1997) or in combination with cationic polymers (Greer, James 1993). Zirconium and titanium salts are also known to react with fatty acids and resin acids to form a zirconium/titanium soap which has a higher glass transition temperature, $T_{\mathrm{g}}$
(Buzby, Evans 1991). Most of the organic deposits have $T_{\mathrm{g}}$ values within the temperature range of typical papermaking operations (ca. $30^{\circ}$ to $60^{\circ} \mathrm{C}$ ). Therefore, any treatment that increases the $T_{\mathrm{g}}$ above this range has the potential to reduce tackiness and diminish deposition problems.

Before leaving the subject of detackification, it should be noted that the word also is sometimes used to describe the effects of nonionic polymers, such as poly(vinyl alcohol), methylcellulose, modified poly(ethylene oxide).

\section{Organic polymers}

Many of the chemical additives found to be effective for control of tacky deposits can be described as organic polymers. Within this category there are huge ranges of molecular mass, charge, and water-loving vs. sparingly soluble character. The effects of polymeric agents are greatly dependent on how these materials interact with surfaces. Fortunately, these mechanisms are described in a number of reviews (van de Steeg et al. 1992; Fleer et al. 1993; Wågberg 2000). The type of polymer employed clearly has an impact on the colloidal stability of dispersed tacky particles (Dreisbach et al. 1996). Important classes of polymeric materials used for pitch and stickies control are considered below.

Very-high-mass, acrylamide-based polyelectrolytes which papermakers call "retention aids," are not usually thought of as deposit-control agents. However, their action in slowing the formation of deposits should not be overlooked. For example, even when talc is used as a primary deposit-control additive, it is recommended to make sure that the talc is being retained efficiently in the paper product (Allen 1980; Carter, Hyder 1993). Likewise, when highly cationic additives are used to coagulate tacky materials on the surfaces of fiber fines and other solids (Dreisbach et al. 1988; Horn and Linhart 1991; Winter et al. 1992; Shetty et al. 1994; Richardson 1995; Gill 1996; Carré et al. 1998; Baumann et al. 2002), it is important to keep these fines from building up in the short circulation system. This can be achieved either with conventional retention aid polymers or with a microparticle retention program (Dixit et al. 1991).

As illustrated in Fig 5, the mechanism by which highmass acrylamide polymers function has been described as polymer bridging (La Mer, Healy 1963; Gregory 1973; Swerin, Ödberg 1997). Efficient bridging requires that the polyelectrolyte interacts with oppositely charged areas on the surfaces with which it comes into contact (Poptoshev, Claesson 2002). Because papermakers often employ highly charged cationic materials somewhere in the process, there are usually sufficient anchoring sites on the solids so that negatively charged retention aids can be used successfully in retention of tacky particles (Winter et al. 1992). Alternatively, high-mass cationic retention aids can interact effectively with uncovered, negative areas on the resinous materials and fibers.

High-charge cationic polymers have been found to be effective for deposit control over a wide range of circumstances (Greer, James 1993; Magee, Taylor 1994; Richardson 1994; Klein, Grossman 1997; Stitt 1998; Kekkonen, Stenius 1999; Song, Ford 2004; Dechandt et 


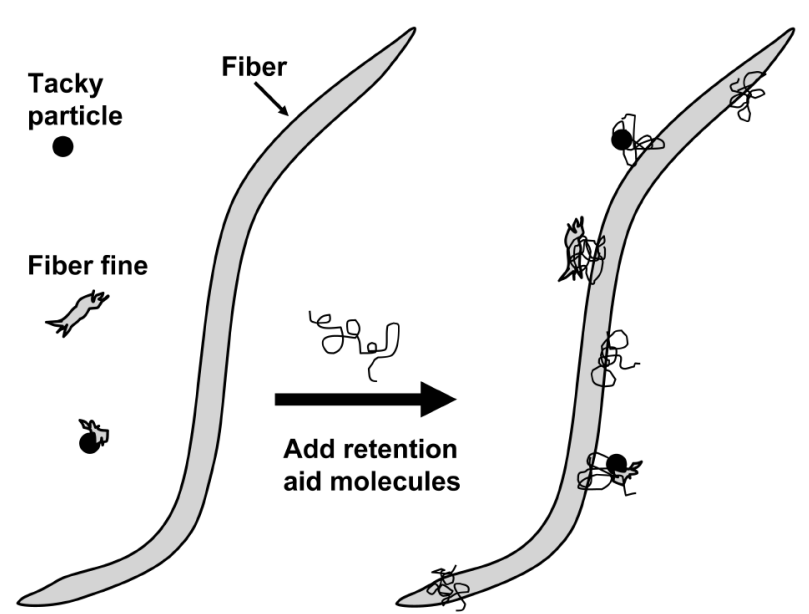

Fig 5. Role of very-high-mass acrylamide-based retention aids in retention of tacky particles. Not to scale, the polymer is shown schematically much larger than actual size to improve clarity of the figure.

al. 2004). Some of these already have been cited in the earlier discussion of certain adsorbent mineral products (Boardman 1996; Curtis et al. 1995). The high-charge cationic polymers most often used in deposit-control applications are quaternary ammonium compounds (Dreisbach et al. 1988) having molecular masses within about 50,000 to 1 million grams per mole. Examples include poly-dimethylamine-epichlorohydrin (Greer, James 1993), poly-diallyldimethylammonium chloride (poly-DADMAC) (Greer, James 1993; Richardson 1995; Colman et al. 1996; Carré et al. 1998), and poly-ethylenimine (PEI) (Winter et al. 1992; Colman et al. 1996; Gill 1996; Baumann et al. 2002). Carré et al. (1998) observed an absence of tackiness following treatment of a suspension of sticky materials with poly-DADMAC, whereas treatment with PEI increased the tackiness under the conditions of testing. Recent work has demonstrated superior performance of a high-charge cationic polymer having a molecular mass almost as high as that of typical retention aids (Dechandt et al. 2004).

Although addition of high-charge cationic polyelectrolytes to paper machine process streams can achieve neutral net surface charges, the mechanisms by which these additives work is expected to be more complex (Shetty et al. 1994). For instance, there is a high likelihood that such additives cover the surfaces unevenly, giving rise to attraction between oppositelycharged patches and uncoated areas on opposing surfaces (Gregory 1973; Rojas et al. 2002). This mechanism is shown schematically in Fig 6. One study demonstrated the ability of highly charged cationic polymers to displace surface-active molecules from the surfaces of tacky substances in suspension (Shetty et al. 1994). The tacky substances subsequently lost their colloidal stability and adhered to fiber surfaces.

The effectiveness of treatment with high-density cationic polyelectrolytes depends on the nature of the tacky substance. In one study, pitch dispersions that were rich in triglyceride fats responded well to treatment with a highcharge cationic polymer (Hassler 1988). However, another suspension, rich in the calcium salts of fatty acids, did not show a promising response to the same polymer.

Hydrophilic polymers of intermediate mass are

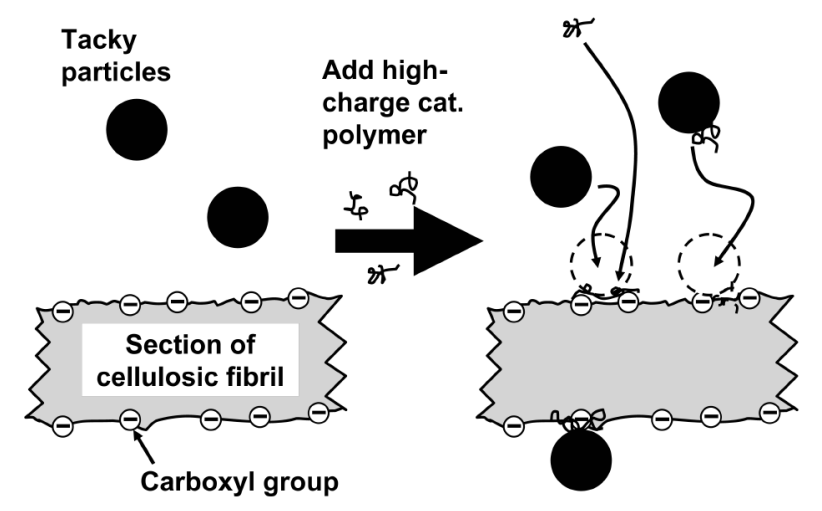

Fig 6. Role of high-charge cationic particles in fixing tacky particles to solid surfaces, with involvement of charged-patch mechanism.

often used for pitch control, and they are sometimes classed as detackifying chemicals (Dreisbach, Michalopoulos 1989; Ling 1993; Laubach 1994; Richardson 1995; Nguyen 1996a,b). It makes logical sense that the waterhating character of natural and synthetic oleophilic materials in a paper machine system can be altered by adsorption of something more hydrophilic onto them (Böhmer et al. 1990). By selecting a molecular mass below about one million $\mathrm{g} / \mathrm{mole}$, such effects can be achieved without inducing the kind of polymer bridging that was described in the previous section. Polyvinyl alcohol is an example of a product that appears to have the appropriate balance of solubility characteristics to work well as a deposit-control agent (Dreisbach, Gomes 1989; Moreland 1989; Nguyen 1996a,b). Other polymers, including methylcellulose, modified poly(ethylene oxide), proteins (Haettich 2002), and hemicellulose components (Clas et al. 1993; Otero et al. 2000; Hannuksela, Holmbom 2004) have shown similar effectiveness. In all these cases the polymers are able to adsorb efficiently onto surfaces that are more hydrophobic than themselves, making those surfaces less prone to adhesion and coalescence. The treated particles are stabilized in the colloidal system, i.e., their coagulation is inhibited.

The ability of hydrophilic polymers to function as antideposit agents can be enhanced by cationic charged groups in some cases. For instance, certain products classed as organic detackifying agents possess a low cationic charge density in order to adsorb more effectively on the surfaces of tacky materials suspended in the system (Richardson 1995). Cationic starch, as used in the emulsion of alkaline sizing agents, appears to play a similar function in stabilizing oleophilic particles in suspension (Knubb, Zetter 2002). The effectiveness of a certain amphoteric, surface-active protein was enhanced by adding it in combination with a high-charge cationic polymer (Haettich 2002).

In mechanistic terms, effects of hydrophilic polymers, having low to moderate charge density, are often said to function by steric stabilization (Hassler 1988; Sundberg et al. 1994b; Morra 2000). In other words, the presence of water-loving tails and loops of macromolecules extending outwards from the surfaces inhibits close approach and adhesion between those surfaces (Rojas et al. 1998; Claesson et al. 2003). Work by Otero et al. (2000) and Mosbye et al. (2003), among others, showed that steric stabilization can explain the pitch-stabilizing ability of 
carbohydrates dissolved in water from thermomechanical pulping. In this case carbohydrates adsorb onto pitch particles and inhibit their deposition onto various minerals, including talc and clay. The tendency of dissolved starch to stabilize pitch and stickies was mentioned earlier (Huo et al. 1999; Zeng et al. 2001).

A recipe for a minimum deposition tendency has been described recently (Stenkamp, Berg 1997), and the approach is worth considering when optimizing polymerbased detackifying systems. Fig 7 represents a type of hydrophilic polymer layer that would be expected to give superior anti-deposit effects. Characteristics of such an adsorbed layer are as follows:

- Continuous, dense hydrophilic layer adjacent to the hydrophobic surface

- Significant steric repulsion between the surfaces when the longest "tails" of water-soluble polymer begin to become compressed as the surfaces approach each other

- A minimization of van der Waals (dispersion) forces between the surfaces, due to the sparcity of the macromolecules having the highest molecular mass

This model assumes that the polymer is attached to the substrate. However, Huo et al. (2002) showed that starch molecules can be considerably adsorbed on the tacky hydrophobic surface.

Polyelectrolytes with partially hydrophobic character might be thought of as a way to achieve favorable solubility characteristics between the polyelectrolyte and the tacky material, ensuring sufficient adsorption onto tacky materials. The adsorption tendency of polyelectrolytes onto tacky materials can be increased by copolymerization or derivatization with hydrophobic substituent groups, such as alkyl chains having 14 to 22 carbons. Various copolymers of cationic, hydrophilic monomers and hydrophobic monomers have shown promise as detackifying agents for resinous materials (Finck et al. 1993; Shetty, Ramesh 1996; Juzukonis, Chen 2000). Alternatively the product may have a hydrophobic molecular chain with hydrophilic pendant groups extending outwards from the surface(s) into the solution phase. Anionic styrene maleic anhydride copolymer also has been claimed as a detackifying agent for secondary fibers (Dahanayake, Yang 2001). As a third possibility, a partially hydrophobic styrene maleic anhydride copolymer can be blended with cationic guar to achieve a preferred balance of properties for stabilization of tacky materials (Hlvika, Wai 1996).

The mechanism by which partially hydrophobic polymers reduce tackiness is most likely related to their surface-active character. Briefly stated, it is assumed that a disproportionate number of the oleophilic groups on the molecules associate themselves with the surface of the tacky materials. This leaves a disproportionate amount of water-loving groups facing toward the aqueous phase. It follows that treatments with partially hydrophobic polymers may have a net dispersing effect, depending on the details of molecular structure.

Block copolymers, involving hydrophilic and hydrophobic groups, are an extreme example of the principle just described, and they are reported to work effectively as stabilizers for tacky materials in paper machine systems (Fogarty 1993; Ling 1994; Pearson 1995). Block

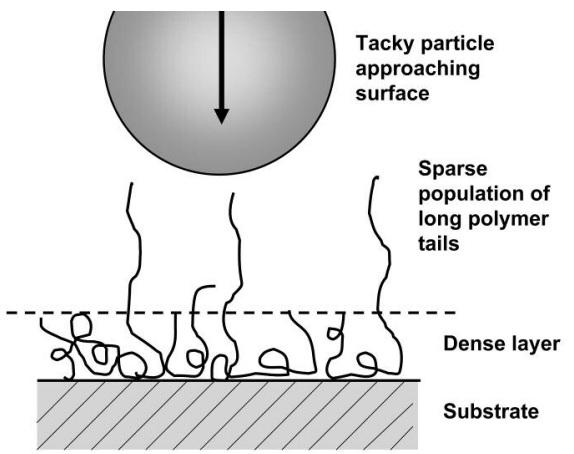

Fig 7. Illustration of "minimum-deposition" treatment concept for hydrophilic polymer layer combining steric stabilization with a minimum dispersion force contribution.

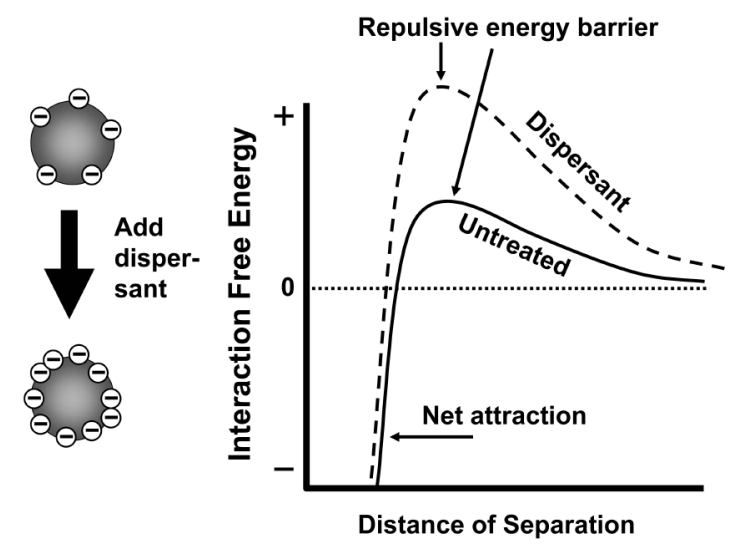

Fig 8. Schematic diagram illustrating effect of dispersant on plot of free energy of interaction vs. separation distance.

copolymers with ethylene oxide and propylene oxide groups (EO/PO) are widely used as a type of polymeric, non-ionic surfactant (Allen 1980; Glazer 1991; Borchardt 1992; Ling 1994; Laubach 1994). By varying the chain length of each portion, suppliers of such compounds can tailor their properties to satisfy a wide range of applications, including emulsification, inverse emulsification, wetting, de-inking, and deposit control.

\section{Dispersants}

Dispersants, when they are recommended for control of tacky deposits, usually come with a suggestion to use them in moderation (Allen 1980; Glazer 1991; Gronfors et al. 1991; Carter, Hyder 1993). Too much of a dispersant chemical is expected to hurt retention efficiency. Various dispersant products are classified as inorganic or organic (Hanu 1993). Phosphates are the dominant family of inorganic dispersants, whereas acrylate polymers are the dominant family of organic ones.

The mechanism by which conventional dispersant additives function in papermaking systems is by contributing a high negative ionic charge to surfaces upon which they adsorb (Hanu 1993). As shown in Fig 8, the increased negative charge of the particle surfaces increases the electrostatic potential energy barrier, inhibiting contact between the surfaces. To be effective, the amount of dispersant needs to be enough to overpower any coagulants which may be present, e.g. aluminum sulfate or highcharge-density cationic polymers.

The use of dispersants has sometimes been criticized on the grounds that it can lead to uncontrolled buildup of dispersed materials in a paper machine system (Gronfors 
et al. 1991). In principle, unretained fine materials either must be retained in the paper or they are more likely to settle out and build up on papermaking equipment. Cationic retention aids, in particular, tend to be deactivated by dispersants. In some cases, however, dispersants have helped papermakers overcome specific deposit problems (Allen 1980; Glazer 1991; Gronfors et al. 1991; Carter, Hyder 1993).

Scale control additives are worth noting at this point, not because they are intended for control of tacky deposits, but because their properties tend to overlap with those of dispersants (Amjad 1995; Wang 2002). Anionic species such as carbonates and oxalates have great affinities for metal ions such as $\mathrm{Ca}^{2+}$, and $\mathrm{Mg}^{2+}$ and will react to form insoluble precipitates. The buildup of these precipitates can lead to scale deposition in operations such as pulping, bleaching, and paper production. The most important variables that control the formation of scale include $\mathrm{pH}$, temperature, total concentrations of scale-forming species, and the presence of other chemicals. Though a discussion of the physical chemistry of scale formation is beyond the scope of this review, suffice it to say that it is a complex subject that involves surface chemistry and heterogeneous nucleation and stability of the various species formed (Smith, Martell 1989; Wang 2002). It so happens that the multivalent, anionic character of the dispersants described in the previous subsection tends to make them effective as sequestrants for multivalent metal ions, such as calcium. Anti-scale treatments also have been claimed for use in combination with biocides for deposit control (McNeel et al. 2001).

\section{Surfactants}

Surfactants can be defined as molecules that have both water-loving and oil-loving groups (Lynn and Bory 1993). The subject of surfactants already has been mentioned in the context of polymeric materials having partial hydrophobic character (see Schick 1987; Miller 1988; Doshi 1992), but it is important to recognize that a wide range of surface-active substances have been found to be effective in various efforts to reduce deposits of tacky materials (Hoekstra, May 1987; Scott 1989; Dykstra, May 1989). As in the case of dispersants, surface-active additives are expected to adversely affect first-pass retention (Magee, Taylor 1994). Sizing, drystrength, and the rate of dewatering also can suffer, especially if the dosage of surfactant is enough to increase the level of entrained air in the system. Foam generation can be a problem, depending on the detailed nature of the surfactant and the conditions of use (Moreland 1986). Typical surfactants used for deposition control include non-ionic, oligomeric compounds such as linear alcohol ethoxylates and alkyl phenol ethoxylates. Among the anionic type, alkyl sulfosuccinic acids have been reported. Polymeric surfactants such as EO/PO copolymers and lignosulfates can be also mentioned. A large number of patents regarding the use of surfactants can be invoked, and in the following we will just describe briefly their general mechanism of action.

Nonionic surfactants have experienced considerable growth in general (Schick 1987), so it is not surprising that the same is true with respect to papermaking applications (Allen 1980; Glazer 1991; Borchardt 1992; Ling 1994; Laubach 1994). The most popular surfactants in this class fall into two categories, those in which the hydrophobic portion of the molecule contains an alkyl group, and those in which the hydrophobic portion is a polypropylene oxide block. In either case, the hydrophilic portion usually is comprised of polyethylene oxide (EO), having repeating $-\mathrm{CH}_{2}-\mathrm{CH}_{2}-\mathrm{O}-$ groups. Superior control of tacky deposits was claimed also when a nonionic surfactant solution was used as the emulsification medium for an organic solvent (Dreisbach, Champine 2002).

Fig 9 offers a schematic view of how nonionic surfactants are likely to adsorb onto oleophilic particles in such a way that the hydrophilic groups provide a barrier to contact. A molecular characterization of typical EO surfactants and their adsorption behaviors on hydrophobic surfaces can be found in recent publications (Stubenrach et al. 2004a,b; Claesson et al. 2005).

Compared to their ionic counterparts, nonionic surfactants are noted for not being affected by $\mathrm{pH}$ and ionic strength (salt). In an aqueous medium they tend to adsorb with the non-polar group facing a hydrophobic surface and with the polar (EO) moieties exposed outwards. The efficiency with which such treatment renders the surfaces hydrophilic and sterically stabilized against sticking collisions can be optimized by varying the masses and ratio of masses of the hydrophobic and hydrophilic parts. In some cases nonionic surfactants may adversely affect downstream operations. For instance, the amounts of hydrophobic sizing treatments needed to meet customer requirements may increase substantially. Short of froth flotation, little can be done to eliminate the effects of nonionic surfactants, once their intended mission is completed. However, the fact that nonionic surfactants tend to be highly temperature sensitive, compared to charged surfactants, provides a potential way to tune their performance for different applications.

To address the issue of nonionic surfactants' expected adverse effect on first-pass retention, a series of tests was carried out in combination with a cationic acrylamidebased retention aid (Capozzi, Rendé 1994, 1995). The nonionic surfactant, when first added to the agitated fiber suspension, caused an immediate increase in the turbidity of filtrate from the suspension, consistent with a decrease of retention of particulate matter onto fibers. Surprisingly, subsequent addition of the cationic retention aid was highly

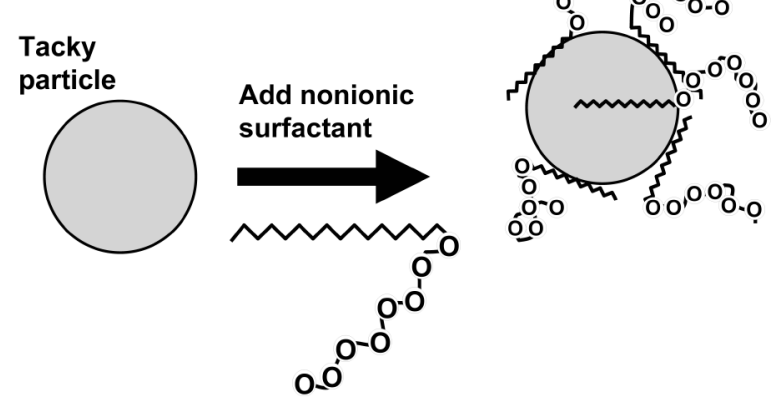

Fig 9. Role of nonionic surfactants in forming a stabilizing hydrophilic layer around a tacky particle. 
effective, as indicated by very low values of filtrate turbidity after treatment. Presumably, the molecular mass of the retention aid was high enough to span the distance between the surfaces of fine particles and fibers, even when those surfaces can be assumed to have been coated by layers of nonionic block copolymer surfactants.

Ionic surfactants are sometimes considered undesirable in industrial applications, since their performance is expected to depend on a myriad of other ionic species in the system where they might be applied. Dreisbach and coworkers (1996) showed, however, that it is possible to use a negatively charged surfactant in combination with a cationic polymer retention aid. Several authors have noted that ionic surfactants can be used effectively to minimize organic or microbiological deposits (Hassler 1988; Robertson, Taylor 1994; Abraham 1998).

A renewed interest in surfactant addition of the paper machine wet end has been sparked by findings that some of them are effective for control of biofilm deposition and growth (Robertson, Taylor 1994; Donlan et al. 2000). Sessile bacteria, which mainly are found attached as continuous colonies on wetted surfaces (Martinelli et al. 2002), tend to be much more relevant for deposit problems, compared to the suspended bacteria that usually show up in bacterial counts, using petri dish techniques. It appears that interactions of the surfactant molecules with cell walls of sessile bacteria can make them more vulnerable to the effects of certain biocides (Donlan et al. 2000). Also, the surfactants may interfere with the adhesion of bacterial cells and other life functions.

\section{Solvents}

Due to the oleophilic nature of the binder materials in most tacky deposits it is expected that organic solvents will be effective for cleaning paper machine systems (Doshi 1992). However, due to concerns about airborne hydrocarbons (Anastas et al. 2001; Allen 2002), the use of organic solvents in paper machine systems is becoming less common. Solvents tend to be used during scheduled shutdowns for removal of especially stubborn deposits. As mentioned in the context of surfactants, another approach is to make solvents more compatible with the water phase by forming an emulsion (Dreisbach, Champine 2002).

Kerosene, which is basically a high-boiling mineral oil, is probably the most commonly used solvent for paper machine cleaning procedures. Kerosene products used in the paper mill for cleaning or as part of water-inoil emulsions generally have high purity requirements. Aromatic compounds are scrupulously excluded from most applications, since contact of such compounds with certain bleaching operations might produce chlorinated compounds of high toxicity. A plant-derived oil, limonene, is sometimes used in place of conventional petroleum-based solvents (Chandler 1997).

\section{Enzymes}

The majority of "pitch" compounds derived from wood belong to the family of mono/di/triglycerides, which all contain ester bonds. Lipases, which hydrolyze such bonds, have been found to be effective against pitch deposits (Skjold-Jørgensen, Lange 1991; Fischer, Messner 1992; Van Haute 2003). A variety of different enzymes or mixtures of enzymes may be used, depending on whether the deposits contain substantial amounts of other materials, such as starch, cellulose, proteins, etc.

It has been found that triglyceride fats often are a main contributor to the tacky nature of wood resins during papermaking operations (Fischer, Messner 1992; Blazey et al. 2002). It was shown, in the case of unbleached sulfite pulp, that pitch problems could be minimized by treatment with lipases, followed by alkaline extraction (Fischer, Messner 1992). Though this treatment did not remove all of the resinous material from the pulp, the tackiness was greatly reduced. Related enzyme treatments of mechanical pulp have been shown to reduce pitch deposits during newsprint production (SkjoldJørgensen, Lange 1991).

When using esterase enzymes for pitch control, the levels of carboxylic acid groups in the tacky substances will tend to increase. For this reason, it makes sense to think in terms of combined or sequential additive programs, including highly charged cationic polymers or positively charged mineral surfaces.

Proteolytic enzymes provide papermakers with an alternative means for attacking biofilms, both during production and during shutdowns (Galon 1998). It has been found that such enzymes can hydrolyze the filaments within bacterial cells that are essential to film formation.

\section{Surface treatments}

So far this review has focused mainly on treatment strategies involving aqueous suspensions. There are additional deposit-control strategies that involve either intermittent or continuous treatment of solid surfaces within the paper machine system. As described below, these strategies include so-called "boilouts" of the system during maintenance shutdowns, selection of construction materials that resist deposit formation, and spray-application of chemicals onto periodically wetted elements such as forming fabrics.

\section{Boilouts}

It is a standard practice in paper mills to periodically shut down operations and clean the wetted surfaces of a paper machine, usually with an emphasis on the short-loop recirculation system and wet-press section (Glazer 1991; Guillory 1998; Guillory, Towery 1998). Papermaking efficiency and product quality often suffer if too much time elapses between such cleanups (Stitt 1997).

The term "boilout," emphasizing the use of elevated temperatures to clean papermaking equipment, should not be taken literally. Steam is often used for the heating of solutions used for wash-ups of the short-loop of paper machine systems, but temperatures are typically in the range of $60-71{ }^{\circ} \mathrm{C}$ (Guillory, Towery 1998). A common practice involves treatment with an alkaline detergent solution, often having a $\mathrm{pH}$ in the range of 10-13. However, depending on the nature of the deposited materials, acidic solutions may also be used. In some cases it is possible to avoid use of high or low $\mathrm{pH}$ solutions by use of enzymes 
capable of breaking down the binder materials in a variety of deposits (Anstey et al. 1998).

\section{Deposit-incompatible surfaces}

Chemical treatments can make it possible to run a paper machine longer, before operating efficiency begins to fall. Another approach is to build the paper machine out of deposit-resistant materials (Kallio, Kekkonen 2005). For example, fluorocarbons can be used in the manufacture of forming fabrics (Fischer 1999). Fluorocarbon coverings are commonly used on dryer cans, especially in the early part of the dryer section on machines using recovered fibers with high levels of sticky materials (Urbanski 1990). A shortcoming of these materials is a relatively low mechanical/surface resistance. They tend to wear out faster as compared to others surfaces within the paper machine system. Recently, stainless steel materials have become available that resist biological fouling in food applications (Santos et al. 2004).

A factor that tends to defeat anti-deposit strategies based on construction materials and polymer compounding of paper machine clothing is the fact that once deposits start to form, the nature of the underlying "clean" surface may become irrelevant. In the case of pitch deposits, oleophilic substances already on a surface can provide an attachment point for like materials coming from the bulk phase. Imperfections, breaks in a coating, or abraded areas may provide a beach-head, upon which deposits may start to build. In addition, there is no construction material that can completely compensate for design deficiencies in a paper machine system, such as dead areas of flow where deposits can settle by gravity.

\section{Cationic spray treatments (passivation)}

Fabrics used in papermaking are mostly made from polymers having relatively low surface energy, and therefore they are prone to organic deposition. The word "passivation" is often used when referring to spray treatments of these forming fabrics and other surfaces that are intermittently wetted by paper machine furnish or whitewater (Doshi 1992). Many papermakers have observed substantial benefits by applying mist showers that contained low concentrations of cationic substances in solution (Rendé 1994; Nguyen, Dreisbach 1998). Highcharge-density cationic polymers (Colman et al. 1996; Kenney, Engstrom 1988; Duffy, Aston 1989; Nguyen, Dreisbach 1998; Aston, Stewart 1991) and aluminum salts (Colman et al. 1996) have been used, sometimes in combination with surfactants.

The mechanism by which passivation treatments appear to work is somewhat counter-intuitive, since cationic polymers and aluminum products might be expected to precipitated negatively charged tacky materials onto the equipment surfaces. However, as proposed by Kenny and Engstrom (1988), results suggest complexation between adsorbed cationic substances and mainly water-loving, negatively charged colloids or polymers present in the process water. Duffy and Aston (1989) found further support for such a mechanism, noting that forming fabrics developed a tan color during continual treatment, consistent with the build-up of a thin layer of hydrophilic material. Nguyen and Dreisbach measured the tack force following different kinds of spray treatments of forming fabrics in intermittent contact with paper machine process water (1998). Their results were consistent with a reduction in tack force due to adsorbed hydrophilic materials. To carry the idea one step further, it is possible to implement successive spray treatments with cationic and anionic hydrophilic polymers to make surfaces resistant to tacky deposits (Welkener, Hassler 1994).

\section{Test methods for tacky deposits}

It can be difficult to achieve credible simulations of production problems by use of laboratory tests. During commercial-scale papermaking it is common for a wetted surface to be exposed to literally tons of materials, with intense flow conditions and elevated temperatures continuing without significant interruption for many days. Though papermaking furnish often contains $1-5 \%$ of pitch or sticky materials, on a weight basis, the proportion of this material that ever becomes involved in deposits usually is quite small. However, even a very small amount of these materials, if deposited in a critical location, may be enough to require a shutdown of a paper machine system.

\section{Coupon tests for in-mill use}

For the reasons just outlined, gravimetric determinations of deposit amounts usually are limited to full-scale paper production. "Coupons," usually consisting of metal or plastic plates, are weighed and then placed so that they are exposed to steady flow (Dreisbach, Michalopoulos 1989; Pelton, Lawrence 1991). The mass of deposit is determined after a certain time, by drying and weighing. Alternatively, the deposited material may be observed microscopically (Pelton, Lawrence 1991). Coupon surfaces also may be extracted to collect and analyze soluble materials. Sometimes the coupons are placed in a side-stream, making it possible to evaluate different chemical treatment options.

An innovative method for monitoring the build-up of biofilms in a paper machine system uses a transparent disk that rotates while partly submerged in process water (Flemming et al. 2001). A decrease in light transmission is used to indicate biofilm growth.

\section{Laboratory methods with enhanced deposition}

Many laboratory-oriented methods for evaluation of prospective deposit-control treatments involve different ways of accelerating the deposition process. One way to achieve this goal is to apply hydrodynamic shear using an agitator. Often the best way to quantify the amount of deposit on the tips of impellor blades is by use of a solvent, followed by chemical analysis.

A more vigorous way to induce deposition of suspended tacky particles onto stainless steel employs a vibrating coupon (Hassler 1988). The momentum of individual tacky particles causes them to impinge upon coupon surfaces.

To evaluate conditions relative to the deposition of 
sticky substances onto a plastic fabric, the Pira research group developed a system in which fabrics are held in metal frames (Abraham 1998). The frames undergo a reciprocating motion, repeatedly drawing the fabric surfaces through the aqueous sample, such that there is flow through the fabric. After a given time, the samples may be weighed or microscopically inspected. A later modification involves additional agitators to accelerate the deposition process (Carré et al. 1998).

Given the high affinity of many tacky materials for plastic surfaces, it makes sense to consider the use of plastic particles as collectors. The plastic particles are weighed before and after exposure to an agitated fiber suspension. One such method entails use of plastic foam as a collector (Ling et al. 1993). Blanco et al. (2000) reported a system for quantifying the deposition onto a rotor. Quantification was achieved by weighing or by image analysis.

\section{Direct observation of process water}

Counts of microscopic particles in a sample of paper machine water are often used to estimate the likelihood of deposit problems (Parmentier 1980b; Winter et al. 1992). Due to their fluid nature, pitch particles often can be recognized by their spherical shape. Unfortunately, the concentration of suspended pitch particles is not necessarily well correlated with the frequency or extent of deposits. Rather, the material in suspension tends to be self-selected as the colloidally-stable, deposit-resistant material.

Recently it has been shown that substantially more can be learned by monitoring colloidal particles in papermaking process water by using spectroscopic analysis at a given probing wavelength (Vähäsalo 2005). Temperature conditions leading to sticking collisions among tacky particles can be revealed by changes in the number concentrations of suspended particles. By flow cytometry, with appropriate use of surface-specific stains, it is possible to identify populations of different particulate components in the whitewater.

\section{Collection and examination of deposit samples}

A whole class of methods can be used to examine either coupons, representing the wetted surfaces of papermaking equipment, or samples of deposits collected from paper machines. Stains can reveal aspects of the hydrophilic, hydrophobic, or charged nature of the deposited material. Bacterial slime can be shown by ATP-type tests. Microscopic methods also can be used to look for objects that have shapes consistent with pitch or stickies.

Detailed chemical analysis can be applied effectively, not only in examination of deposits, but also to track the amounts and ratios of different potentially tacky substances in wood, waste paper, or solvent-extracts from the papermaking process streams. Work by Blazey et al. (2002) showed that the ratio between triglyceride fats and fatty acids in wood pitch can have a very high correlation to the frequency of deposit problems. Infrared analysis can quickly show whether a given deposit is predominantly pitch-derived, rich in synthetic resins, biological, or mainly inorganic.

\section{Wettability}

The laboratory-oriented methods discussed up to this point are mainly appropriate for deposit problems that either have already occurred, or there is so much tacky material present in the system that the listed methods are able to achieve statistically significant results. Looking to the future, it would be a great advantage to be able to rapidly quantify the initial, trace amounts of resinous material that deposit onto a test surface during a relatively short period of time. Such a method would make it more feasible to carry out meaningful tests in the lab with moderate amounts of papermaking furnish, while avoiding the need to "spike" samples with unrealistic levels of contaminant. Alternatively, it might then be possible to place a probe into different parts of a running paper machine system and obtain prompt feedback about the initial rate of deposition of tacky materials.

In principle, techniques involving measurement of contact angles on test surfaces are particularly well suited to detection of tacky deposits at their initial stages of formation. Theoretical and experimental studies have shown that contact angles sense the outermost molecular layers of surfaces (Fowkes 1965; Shafrin, Zisman 1967; Good 1973; Morra et al. 1990; Mantel, Wightman 1994; Extrand 2004). Based on measured contact angles it is possible to characterize critical surface tensions of various solid surfaces, either clean or contaminated. It is even possible to detect sub-monolayer quantities of deposited material. The main requirement is that the adsorption one wishes to detect must significantly affect the wettability of the selected substrate. Related tests were carried out by Ling (1993) who measured the contact angles of oil droplets on the immersed surfaces of various deposits. In other work the size of bubbles attached to immersed surfaces was evaluated as a means of judging surface energy parameters (Ling 1994).

\section{Closing comments}

With so many types of tacky materials, each with its own range of composition-dependent behaviors, and so many potential interactions between these materials and other components of a paper machine system, it can be a challenge to identify the most cost-effective and reliable deposit control strategies. As was shown in sections 3 and 4 of this review, there are a great many different depositcontrol strategies that might be applied, either individually or in various combinations. All of this adds up to a great deal of challenging work, including opportunities for the next generation of papermaking technologists and scientists.

Fortunately, as documented in the literature cited here, substantial progress has been achieved with respect to the organic chemistry, colloidal stability, tacky characteristics, and analytical detection of substances tending to form tacky deposits in paper machine systems. Many new treatment strategies to fight tacky deposits have been developed, and it can be expected that the pace of such innovations will continue. Of the various barriers that tend to stand in the way of prompt, cost-effective resolution of tacky deposit issues, one of the most critical 
involves the need for rapid detection methods for deposited material, especially if those methods can be employed automatically during operation of a paper machine. Ultra-sensitive methods, such as those based on wettability principles, as discussed in the previous subsection of this review, hold out the potential for much more rapid and thorough optimization of deposit-reduction strategies for paper machines in the years ahead.

\section{Literature}

Abraham, S. (1998): Successful approaches in avoiding stickies, Tappi, 81(2), 79. Allen, D. T. (2002): "Green Engineering: Environmentally Conscious Design of Chemical Processes," Prentice Hall, Upper Saddle River, NJ.

Allen, L. H. (1980): Mechanisms and control of pitch deposition in newsprint mills, Tappi, 63(2), 81.

Allen, L. H., Cavanagh, W. A., Holton, J. E., and Williams, G. R. (1993): New understanding of talc addition may help improve control of pitch, Pulp Paper, 67(13), 89.

Amjad, Z., Ed., (1995): "Mineral Scale Formation and Inhibition," Plenum Press, New York.

Amjad, Z., Zuhl, R. W., and Zibrida, J. F. (2000): Effect of cooling water impurities on deposit control polymer performance, Mater. Perf. 39(5), 54.

Anastas, P. T., Heine, L. G., and Williamson, T. C., Eds. (2001): "Green Engineering," Amer. Chem. Soc., Oxford Univ. Press, Washington, DC.

Anstey, M., King, V., and Dykstra, G. (1998): Practical side of newer depositcontrol technologies, Preprints 84th Annual Meeting of the Technical Section, CPPA: Papers A299.

Aston, D. A., and Stewart, N. (1991): Controlling deposits on paper machine felts using cationic polymer and cationic surfactant mixture, US pat. 4, 995, 944.

Back, E. L. (2000): Resin in suspensions and mechanisms of Its deposition, in "Pitch Control, Wood Resin and Deresination," Edited by E. L. Back and L. H. Allen, TAPPI Press, Atlanta, Georgia.

Back E. L., and Allen L. H., Eds. (2000): "Pitch Control, Wood Resin and Deresination," TAPPI Press, Atlanta, Georgia.

Back, E. L., and Salmén, N. L. (1982): Glass transitions of wood components hold implications for molding and pulping processes, Tappi, 65(7), 107.

Barton, A. F. M. (1982): The application of cohesion parameters to wetting and adhesion - a review, J. Adhesion, 14(1), 33.

Baumann, P., Esser, A., Rubenacker, M., et al. (2002): Productivity gains through optimized use of fixing agents, Wochenbl. Papeirfabr. 130(22), 1504.

Blanco, A., Negro, C. Concepción Monte, M., Otero, D., and Tijero, J. (2000): New system to predict deposits due to DCM destabilization in paper mills, Pulp Paper Can. 101(9), T240.

Blankenburg, I., and Schulte, J. (1996): Ecologically compatible slime and deposit control, Wochenbl. Papierfabr. 124(17), 742.

Blazey, M. A., Grimsley, S. A., and Chen, G. C. (2002): Indicators for forecasting 'pitch season,' Tappi J. 1(10), 28.

Boardman, D. (1996): Use of organophilic mineral particulates in the control of anionic trash-like pitch, Proc. Papermakers Conf., 535, TAPPI Press, Atlanta.

Böhmer, M. R., Evers, O. A., and Scheutjens, J. M. H. M. (1990): Weak polyelectrolytes between two surfaces: adsorption and stabilization, Macromolecules, 23(8), 2288.

Borchardt, J. K. (1992): Chemical structure - property relationships of deinking surfactants, Prog. Paper Recycling, 1 (2): 45-60 (1992).

Bottéro, J. Y., Cases, J. M., Flessinger, F., and Poirier, J. E. (1980): Studies of hydrolyzed aluminum chloride solutions. 1. Nature of aluminum species and composition of aqueous solutions, J. Phys. Chem. 84(22), 2933.

Bottéro, J.-Y., and Fiessinger, F. (1989): Aluminum chemistry in aqueous solution, Nord. Pulp Paper Res. J. 4(2), 81.

Bouffard, S. C., and Duff, S. J. B. (1999): White water treatment using organically tailored heulandite minerals, Tappi, 82(7), 178.

Braitberg, L. D. (1966): Controlling pitch accumulations in paper mill systems, Tappi, 49(11), 128A.
Brink, M. W. (1997): Recycled Fiber Use vs. Paper Machine Runnability - You Can Win!, Proc. Eng. Papermakers Conf., 51, TAPPI Press, Atlanta.

Buzby, J. H., and Evans, R. D. (1991): Method for controlling pitch deposits in pulp and papermaking processes with organotitanium (IV) compound, US pat. 4,985,120.

Capozzi, A. M., and Rendé, D. S. (1994): Particle management: An effective stickie control approach, Proc. Pulping Conf., 643, TAPPI Press, Atlanta.

Capozzi, A. M., and Rendé, D. S. (1995): Particle management; Innovations in stickie control, Proc. Recycling Symp., 79, TAPPI Press, Atlanta.

Carré, B., Brun, J., and Galland, G. (1998): The incidence of the destabilization of the pulp suspension on the deposition of secondary stickies, Pulp Paper Can. 99(7): T248.

Carter, R. D., and Hyder, J. (1993): Treated Kaolin Combines Effective Pitch Control with Handling Ease, Pulp Paper, 67(11): 87.

Chandler, W. C. (1997): Industrial solvent based on a processed citrus oil for cleaning up petroleum waste products, US pat. 5,549,839.

Chen, J., Hubbe, M. A., Heitmann, J. A., Argyropoulos, D. S., and Rojas, 0. J. (2004): Dependency of polyelectrolyte complex stoichiometry on the order of addition. 2. Aluminum chloride and poly-vinylsulfate, Colloids Surf. A246(1-3), 71. Claesson, P. M., Dedinaite, A., and Rojas, 0. J. (2003): Polyelectrolytes as adhesion modifiers, Adv. Colloid Interface Sci. 104: 53.

Claesson, P. M., Kjellin, M., Rojas, 0. J., and Stubenrauch, C. (2005): Shortrange interactions between non-ionic surfactant layers, Phys. Chem. Chem. Phys., invited review to appear.

Clas, S.-D., Koller, E., and Allen, L. H. (1993): Characterization of the effect of hemicellulose on the deposition of calcium soaps of tall oil using factorial design analysis, J. Pulp Paper Sci. 19(5), J177.

Colman, I., Duckworth, W., and Stork, G. (1996): Selection of products for deposit prevention," Proc. 1996 Int'l. Paper \& Coating Symp., 221.

Comyn, J. (1997): "Adhesion Science," RSC Paperbacks, The Royal Society of Chemistry, Cambridge, UK.

Crawford, R. A., and Flood, T. A. (1989): Preliminary NMR study on structure of polyaluminum chloride, Proc. Papermakers Conf., 55, TAPPI Press, Atlanta.

Curtis, J., Agbje, H., Woodward, J., Vaska, A., and Gaudreault, R., (1995): Method for removing stickies from wastepaper using modified cationic kaolin, US pat. $5,540,814$.

Dahanayake, M. S., and Yang, J. (2001): Acrylic acid/maleic acid copolymers as detackification agents for adhesives contained in secondary fiber, US pat. 6,235,149. Daignault, L., and Jones, D. R. (2003): The importance of cleaning and deposit control in improving paper machine efficiency, Pulp Paper Can. 104(8): T194.

Dechandt, A., Watkins, T., and Pruszynski, P. (2004): Total approach to deposit control on newsprint machine using, TMP and DIP pulp mix from specialized fixation of individual pulps to retention, Appita J. 57(1), 13.

Derjaguin, B., and Landau, L. (1941): Theory of the stability of strongly charged lyophobic sols and of the adhesion of strongly charged particles in solution of electrolytes, Acta Physicochim. URSS 14: 633.

Derrick, A. P. (1994): Method for controlling pitch, US pat. 5,368,692.

Dixit, M. K., Maleike, T. A., and Jackowski, C. W. (1991): Retention strategies for alkaline fine papermaking with secondary fiber - A case history, Tappi J. 74(4), 107. Donlan, R. J., Elliot, D. L., Gill, J. S., Wiatr, C. L., and Ten Eyck, P. R. (2000): Methods for reducing deposit formation on surfaces, US pat. 6,139,830.

Doshi, M. R. (1991): Properties and control of stickies, Prog. Paper Recycling, 1(1), 54. Doshi, M. R. (1992): Quantification, control, and retention of depositable stickies, Prog. Paper Recycling, 2(1), 45

Douek, M., Guo, X.-Y., and Ing, J. (1997): An overview of the chemical nature of deposits/stickies in mills using recycled fiber, Proc. Recycling Symp., 313, TAPPI Press, Atlanta.

Dreisbach, D. D., and Gomes, G. S. (1989): Process for controlling pitch deposition from pulp in papermaking systems, US pat. 4,871,424.

Dreisbach, D. D., and Champine, J. N. (2002): Method and composition for preventing pitch deposits in paper mills using resinous mechanical pulps, US pat. 6,369,010.

Dreisbach, D. D., Gomes, G. S., and Schuster, M. A. (1988): Pitch control process utilizing quaternized polyamine ionene polymer, US pat. 4,765,867.

Dreisbach, D. D., Laurint, M. E., and Ling, T.-F. (1996): Method for inhibiting the deposition of organic contaminants in pulp and papermaking processes, US pat. $5,555,510$. 
Dreisbach, D. D., and Michalopoulos, D. L. (1989): Understanding the behavior of pitch in pulp and paper mills, Tappi J. 72(6), 129.

Drennen, T. J., and Gill, R. A. (1980): Process for controlling pitch in papermaking, US pat. 4,190,491.

Duffy, R. J., and Aston, D. A. (1989): A novel chemical approach to stickies control, Pulp Paper Can. 90(7), T251.

Dykstra, G. M., and May, O. W. (1989): Controlling stickies with water soluble polymers, Proc. Pulping Conf., 81, TAPPI Press, Atlanta.

Dykstra, G. M. (1992): Sizing short course notes, 109, TAPPI Press, Atlanta.

Edwards, J. C. (1996): Biocides - Bug killers that enhance pulpmaking and papermaking processes, Tappi J. 79(7), 71.

Einstein, A. (1956): "Investigation on the Theory of Brownian Movement," Furth, R., Ed., Dover, New York.

Ekman R., and Holmbom B. (2002): The chemistry of wood resin, in "Pitch Control, Wood Resin and Deresination," Edited E. L. Back and L. H. Allen, Ch. 2, 37, TAPPI Press, Atlanta.

Elsby, L. E. (1986): Experiences from tissue and board production using stickies additives, Proc. Pulping Conf., Book 1: 187, TAPPI Press, Atlanta.

Extrand, C. W. (2004): Contact angles and their hysteresis as a measure of liquid-solid adhesion, Langmuir, 20(10), 4017.

Farley, C. E. (1977): Causes of pitch problems and a laboratory method of evaluating control agents, Proc. Papermakers Conf., 23, TAPPI Press, Atlanta.

Finck, M. R., Greer, C. S., and Ramesh, M. (1993): Hydrophobic polyelectrolyte coagulants for the control of pitch in pulp and paper systems, US pat. 5,246,547. Fischer, B. H. (1999): Reduction in pitch adherence of machine clothing, Tappi J. 82(11), 50.

Fischer, K., and Messner, K. (1992): Reducing troublesome pitch in pulp mills by lipolytic enzymes, Tappi J. 75(2), 130.

Flanagan, J. (2002): The passage of pressure sensitive adhesives through a single slot, Prog. Paper Recycling, 11(3), 17.

Fleer, G. J., Cohen-Stuart, M. A., Scheutjens, J. M. H. M., Cosgrove, T., and Vincent, B., Eds. (1993): "Polymers at Interfaces," Chapman and Hall, London.

Flemming, C. A., Palcic, M. M., Elliott, R. B., and Teodorescu, G. (2001): Novel optical fouling monitor for deposit control, Pulp Pap. Can. 102(10), 53.

Fogarty, T. J. (1993): Cost-effective, common sense approach to stickies control, Tappi J. 76(3), 161.

Fowkes F. M. (1965): Attractive forces at interfaces, J. Colloid Interface Sci. 28, 493. Froass, W. C., Francis, R. C., Dence, C. W.., and Lefevre, G. (1997): The interactions of calcium, magnesium, and silicate ions under alkaline conditions, $\mathrm{J}$. Pulp Paper Sci. 23(7), J318.

Galon, E. (1998): Applications of enzymes in papermaking, Papeterie, 215/216(34), 34.

Gill, B. J. (1974): Controlling pitch deposits in pulp mills with talc, Pulp Paper, 48(8), 104.

Gill, R. I. S. (1996): Chemical control of deposits - scopes and limitations, Paper Technol. 37(6), 23.

Glazer, J. A. (1991): Overview of deposit control, Tappi J. 74(7): 72.

Goldberg, J. Q. (1987): Use of zirconium chemical in sticky contaminants control, Proc. Pulping Conf., Book 3: 585, TAPPI Press, Atlanta.

Good, W. R. (1973): A comparison of contact angle interpretations, J. Colloid Interface Sci. 44(1), 63.

Greer, C. S., and James, N. P. (1993): Synergistic pitch control process utilizing ammonium zirconium carbonate and cationic polymers, US pat. 5,230,774.

Gregory, J. (1973): Rates of flocculation of latex particles by cationic polymers, J. Colloid Interface Sci. 42(2), 448.

Gronfors, H., Valtonen, T., and Blixt, T. (1991): Use of cationic deposit-control agents, Paperi Puu. 73(1), 48.

Gruber, E., Grobmann, K., and Pätzold, R. (1998): Characterization of micro dispersed stickies from recycled paper, Wochbl. Papierfabr. 126(13), 645.

Guillory, K., and Towery, C. (1998): Paper machine and additive system boilouts, Tappi J. 81(7), 66.

Guillory, K. (1998): Implementing an effective boilout program, Tappi J. 81(9), 81.

Haettich, T., Angle, C. D., and Knight, P. (2002): A novel and effective method to manage contaminants in packaging papermaking, Paperi Puu, 84(7), 458.

Hanu, W. M. (1993): "Dispersants," in Kirk-Othmer Encyclopedia of Chemical Technol., 4th Ed., Vol. 8, 293-311, Wiley-Interscience, NY.

Harrison, J. M. M., Freeman, G. M., Marshall, C. J., Jr., Marvin, J. C., and
Lareau, A. F. (1996): Process for treating kaolin clays for pitch control in papermaking and the treated clays and their use, US pat. 5,534,057.

Hannuksela, T., and Holmbom, B. (2004): Stabilization of wood-resin emulsions be dissolved galactoglucomannans and galactomannans, J. Pulp Paper Sci. 30(6), 159.

Haslam, J. H., and Steele, F. A. (1936): The retention of pigments in paper, Tech. Assoc. Papers, 19, 249.

Hassler, T. (1988): Pitch deposits in papermaking and the function of pitch control agents, Tappi J. 71(6), 195.

Heindel, T. J. (1999): Fundamentals of flotation deinking, Tappi J. 82(3), 115.

Hiemenz, P. C. and Rajagopalan, R. (1997): "Principles of Colloid and Surface Science," 3rd Ed., Dekker, New York.

Hlvika, L. M., and Wai, G. K. (1996): Process for controlling the deposition of pitch with a blend of derivatized cationic guar and styrene maleic anhydride copolymer, US pat. 5,744,003.

Hodgson, K. T. (1997): Surface science and process factors affecting removal of sticky contaminants, Prog. Paper Recycling, 6(2), 80.

Hoekstra, P. M. (1991): Fundamentals of slime control, Chem. Processing Aids Short Course Notes, 55, TAPPI Press, Atlanta.

Hogg, R., Healy, T. W., and Fuerstenau, D. W. (1966): Mutual coagulation of colloidal dispersions, Trans. Faraday Soc. 62(6), 1638.

Horn, D., and Linhart, F. (1991): Retention aids, in Paper Chemistry, Edited J. Roberts, Ch. 4, 44, Blackie, Glasgow.

Hsu, N. N.-C., Schroeck, J. J., and Errigo, L. (1997): Identification of the origins of stickies in deinked pulp, Tappi J. 80(4), 63.

Huang, C., and Pan, J. R. (2002): Coagulation approach to water treatment, in "Encyclopedia of Surface and Colloid Science," Edited P. Somasundaran, Vol. 1, 1049, Dekker, New York.

Hubbe, M. A. (2005): Microparticle programs for drainage and retention, in "Micro and Nanoparticles in Papermaking," Edited J. M. Rodriguez, 1, TAPPI Press, Atlanta.

Huhtamäki, M. (2003): Closing the water cycles - How far can we go? Paper Technol. 44(10), 27

Huo, X. (2002): Adhesive contaminants (stickies): Characterization and their interaction with papermaking components during paper recycling," PhD Diss., North Carolina State Univ., Raleigh, NC, available at http://www.lib.ncsu.edu/theses/available/etd-05212002-102529/

Huo, X., Venditti, R. A., and Chang, H.-M. (1999): Effect of papermaking components on adhesive contaminant (stickies) characteristics after pulping, Proc. Recycling Symp., 681, TAPPI Press, Atlanta.

Huo, X., Venditti, R. A., and Chang, H.-M. (2001): Effect of cationic polymers, salts, and fibers on the stability of model micro-stickies, J. Pulp Paper Sci. 27(6), 207.

Huo, X., Venditti, R. A., and Chang, H.-M. (2002): The adsorption of starches on pressure-sensitive adhesive material and its impact on agglomeration, Proc. Pulping Conf., TAPPI Press, Atlanta.

Hyder, W. J., Kunkle, A. C., and Weaver, R. M. (1991): Aluminum chlorohydrate or hydrotalcite treated kaolin clays for pitch control, US pat. 5,037,508.

Juzukonis, W. A., and Chen, S.-R. T. (2000): Composition and methods for controlling stickies, US pat. 6,090,905.

Kallio, T., and Kekkonen, J. (2005): Fouling in the paper machine wet end, Tappi J. $4(10), 20$.

Kekkonen, J., and Stenius, P. (1999): The effect of short-chain cationic polymers on the deposition of wood resin emulsion droplets on silica surfaces, Colloids Surf. A 156(1-3), 357.

Kenney, R. M., and Engstrom, G. G. (1988): New technology for stickies/pitch control with increased production/profitability, Proc. Pulping Conf., 339, TAPPI Press, Atlanta.

Klein, R., and Grossman, H. (1997): The measurement and control of microdisperse and colloidal stickies, Paper Technol. 38(5), 45.

Knubb, S., and Zetter, C. (2002): Deposit study of alkylketene dimer dispersions, Nordic Pulp Pap. Res. J. 17(2), 164.

Knudson, M. I. (1993): Bentonite in paper: the rest of the story, Proc Papermakers Conf., 141, TAPPI Press, Atlanta.

Lamar, R. S., Pratt, W. E., Weber, K. E., and Roeder, R. E. (1990): Method of reducing pitch in pulping and papermaking operations, US pat. 4,964,955.

La Mer, V. K., and Healy, T. W. (1963): Adsorption-flocculation reactions of macromolecules at the solid-liquid interface, Rev. Pure Appl. Chem. 13, 112. 
Laubach, G. D. (1994): Innovations in coated broke treatment programs, Proc. Papermakers Conf., 15, TAPPI Press, Atlanta.

Lindholm, G. (1998): Reduction of fresh water consumption in pulp and paper production, Paperi Puu, 80(4), 260 (1998).

Ling, T. F., Hall, J. D., and Walker, M. M. (1993): Novel test method for evaluating stickies deposition control, Pulp Paper Can. 94(12), 85.

Ling, T. F. (1993): Modifying surface properties of sticky materials through polymer/surfactant adsorption, Pulp Paper Can. 94(10), 17.

Ling, T. F. (1994): Effects of surface properties on stickies removal by flotation, Pulp Paper Can. 95(12), 109.

Ling T. F. (1998): Agglomeration tendency of contaminants in recycled fibers, Tappi J. 81(3), 161.

Lucas, B. E., Venditti, R. A., and Jameel, H. (2001a): Behavior of pressure sensitive adhesive material in industrial pressure screens and laboratory screens, Tappi J. 84(5), 70.

Lucas, B. E., Venditti, R. A., and Jameel, H. (2001b): Breakage and extrusion of pressure sensitive adhesives in industrial and laboratory screening processes, Proc. Pulping Conf., TAPPI Press, Atlanta.

Lynn, J. L., Jr., and Bory, B. H. (1993): Surfactants, in "Kirk-Othmer Encyclopedia of Chemical Technol.," 4th Ed., Vol. 23, 478, Wiley-Interscience, New York.

Magee, K. L., and Taylor, J. L. (1994): Pitch fixation/emulsification in newsprint: mechanisms and mill experiences, Proc. Papermakers Conf., 621, TAPPI Press, Atlanta.

Mantel, M., and Wightman, J. P. (1994): Influence of the surface chemistry on the wettability of stainless steel, Surface Interface Analysis, 21(9): 595.

Martinelli, D., Bunk, M., Cadalbert, B., and Kolb, W. (2002): The language of bacteria: Biofilms in the paper industry, Paper Technol. 43(8), 47.

Matijeviç, E., and Stryker, L. J. (1966): Coagulation and reversal of charge of lyophobic colloids by hydrolyzed metal ions. III. Aluminum sulfate, J. Colloid Interface Sci. 22, 68.

McLaren, A. D. (1948): Adhesion of high polymers to cellulose. Influence of structure, polarity, and tack temperature, J. Polymer Sci. 3(5), 652.

McLaren, A. D., and Seiler, C. J. (1949): Adhesion. III. Adhesion of polymers to cellulose and alumina, J. Polymer Sci. 4, 63.

McNeal, M. R., Nanko, H., and Hubbe, M. A. (2005): Imaging of macromolecular events occurring during the manufacture of paper, Proc. XIII Fundamental Research Symp., Cambridge.

McNeel, T. E., Comstock, D. L., Anstead, M. Z., and Clark, R. A. (2001): Method and compositions for minimizing biological and colloidal fouling, US pat. $6,180,056$.

Menke, L. (1998): Microstickies - Troublemakers in water recirculation loops, Wochbl. Papierfabr. 126(5), 187.

Miller, P. C. (1988): Chemical treatment programs for stickies control, in "Recycling Paper - From Fiber to Finished Product," Vol. 2, 471, TAPPI Press, Atlanta.

Moreland, R. D. (1986): Stickies control by detackification, in "Recycling Paper From Fiber to Finished Product," Vol. 2, 508, TAPPI Press, Atlanta.

Moreland, R. D. (1989): Detackification of adhesive materials contained in secondary fiber with polyvinyl alcohol, US pat. 4,886,575.

Morra, M. (2000): On the molecular basis of fouling resistance, J. Biomater. Sci. Polymer Edn. 11(6), 547.

Morra, M., Occhiello, E., and Garbassi, F. (1990): Knowledge about polymer surfaces from contact angle measurements, Adv. Colloid Interface Sci. 32(1), 79.

Mosbye, J., Foss, H. M., and Laine, J. (2003): Interaction between model colloidal wood resin, fillers, and dissolved substances, Nord. Pulp Paper Res. J. 18(2), 194.

Moss, C. S. (1997): Theory and reality for contaminant removal curves, Tappi J. 80(4), 69 .

Nahley, T. (1995): Microbiological deposit control: key elements, PIMA Mag. 77(12), 50.

Napper, D. H. (1997): Steric Stabilization, J. Colloid Interface Sci. 58(2), 390.

Neuman, R. D. (1975): Calcium-binding in stearic acid monomolecular films, J. Colloid Interface Sci. 53(2), 161.

Neuman, R. D., Swanson, J. W. (1980): Multilayer deposition of stearic acid-calcium stearate mono-molecular films, J. Colloid Interface Sci. 74(1), 244.

Neuman, R. E. (1976): Stearic acid and calcium stearate monolayer collapse, J. Colloid Interface Sci. 56(3), 505.

Nguyen, D. Y. (1996): Methods for inhibiting the deposition of organic contaminants in pulp and papermaking systems using a composition comprising of polyvinyl alcohol and gelatin, US pat. 5,536,363.

Nguyen, D. Y. (1996): Method for inhibiting deposition in pulp and papermaking systems using a composition comprising of polyvinyl alcohol, gelatin and cationic polymer, US pat. 5,723,021.

Nguyen, D. T., and Dreisbach, D. D. (1998): Prevention of pitch and stickies deposition on paper forming wires via adsorption of cationic polymer associated with anionic species, Tappi J. 81(6), 143.

Nnebe, I. M., Tilton, R. D., and Scheider, J. W. (2004): Direct force measurements of the stability of poly(ethylene glycol)-polyethylenimine graft films, J. Colloid Interface Sci. 276(2), 306.

Olsson, A. M., and Salmen, L. (2004): The softening behavior of hemicelluloses related to moisture, ACS Symp. Ser. 864, 184.

Ormerod, D. L., and Hipolit, K. J. (1987): Aluminum control prevents stickies problems, Proc. Pulping Conf., Book 3, 597, TAPPI Press, Atlanta.

Otero, D., Sundberg, D., Blanco, A., Negro, C., Tijero, J., and Holmbom, G., (2000): Effects of wood polysaccharides on pitch deposition, Nord. Pulp Paper Res. J. 15, 607.

Parmentier, C. J. (1980a): Analyzing and controlling deposits in pulp and paper mills, PIMA Mag. 62(7), 33.

Parmentier, C. J. (1980b): Cost-effective pitch control with pitch particle monitoring, Paperi Puu, 62(8), 479.

Patel, S. N., and Banerjee, S. (1999): Deposition of hot melt and wax on surfaces, Tappi J. 82(11), 99.

Pearson, J. E. (1995): Use of dispersion polymers for coated broke treatment, US pat. 5,466,338.

Pelton, R., and Lawrence, D. (1991): A new laboratory approach for evaluating kraft mill pitch deposit control additives, J. Pulp Paper Sci. 17(3), J80.

Pietschker, D. A. (1996): The 100\% closed water system - What to expect, Proc. Papermakers Conf., 521, TAPPI Press, Atlanta.

Poptoshev, E., and Claesson, P. M. (2002): Forces between glass surfaces in aqueous polyethylenimine solutions, Langmuir, 18(7), 2590.

Potter, F. S. (1996): The analysis and chemistry of aluminum based paper machine deposits, Proc. Papermakers Conf., 315, TAPPI Press, Atlanta.

Qin, M., Hannuksela, T., and Holmbom, B. (2004): Deposition Tendency of TMP Resin and Related Model Mixtures, J. Pulp Paper Sci. 30, 279.

Rende, D. S. (1994): Wire deposit control and barrier chemistry, PIMA, 76(2), 32. Richardson, P. F. (1994): Melamine formaldehyde polymer for pitch control, US pat. 5,286,347.

Richardson, P. F. (1995): New technology for pitch and stickies control, Proc. Papermakers Conf., 205, TAPPI Press, Atlanta.

Robertson, L. R., and Taylor, N. R. (1994): Biofilms and dispersants - A less toxic approach to deposit control, Tappi J. 77(4), 99.

Rodgriguez, J. M. (2005): Clay Minerals, in "Micro and Nanoparticles in Papermaking," Edited J. M. Rodriguez, Ch. 8, 141, TAPPI Press, Atlanta.

Rojas, 0. J. (2002): Adsorption of polyelectrolytes on mica, in "Encyclopedia of Surface and Colloid Science," Edited A. Hubbard 517, Marcel Dekker, New York.

Rojas, O. J., Claesson, P. M., Muller, D., and Neuman, R. D. (1998): The effect of salt concentration on adsorption of low-charge-density polyelectrolytes and interactions between polyelectrolyte-coated surfaces, J. Colloid Interface Sci. 205(1), 77.

Rojas, 0. J., Ernstsson, M., Neuman, R. D., and Claesson, P. M. (2002): Effect of polyelectrolyte charge density on the adsorption and desorption behavior on mica, Langmuir, 18(5), 1604.

Rudie, A. (2000): Barium sulfate scale in the fiberline, Tappi J. 83(10), 50.

Saastamoinen, S., Neimo, L., and Paulapuro, H. (1995): Some factors affecting desorption of silicate in the white water system of a paper machine, Paperi Puu, 77(3), 127.

Saffman, P. G., and Turner, J. S. (1956): On the collision of drops in turbulent clouds, J. Fluid Mech. 1(1), 16.

Salmén, N. L., Kolseth, P., and de Ruvo, A. (1985): Modeling the softening behavior of wood fibers, J. Pulp Paper Sci. 11(4), J102.

Santos, 0., Nylander, T., Rosmaninho, R., Rizzo, G., Yiantsios, S., Andritsos, N., Karabelas, A., Muller-Steinhagen, H., Melo, L., Boulange- Petermann, L., Gabet, C., Braem, A., Tragardh, C., and Paulsson, M. (2004): Modified stainless steel surfaces targeted to reduce fouling - Surface characterization, J. Food Engineering, 64(1), 63.

Scalfarotto, R. E. (1985): Remedies for press picking boost efficiency of ASA synthetic sizing, Pulp Paper, 59(4), 126. 
Schick, M. J., Ed. (1987): "Nonionic Surfactants: Physical Chemistry," Marcel Dekker, New York.

Scott, W. E. (1989): A survey of the various contaminants present in recycled wastepaper white water system, Proc. Pulping Conf., 69, TAPPI Press, Atlanta.

Shafrin, E. G., and Zisman, W. A. (1967): Critical surface tension for spreading on a liquid substrate, J. Phys. Chem. 71(5), 1309.

Shetty, C. S., Greer, C. S., and Laubach, G. D. (1994): A likely mechanism for pitch deposition control, Tappi J. 77(10), 91.

Shetty, C. S., and Ramesh, M. (1996): Silicon polyelectrolytes for pitch-deposit control, US pat. 5,527,431.

Sihvonen, A. -L., Sundberg, K., Sundberg, A., and Holmbom, B. (1998): Stability and deposition tendency of colloidal wood resin, Nord. Pulp Paper Res. J. 13(1), 64.

Simons, B., da Silva Santos, C., and Meier, M. (2004): Improving productivity through microbiological deposit control management, Paperi Puu, 86(5), 349.

Skjold-Jørgensen, S., and Lange, N. K. (1991): Enzymes - for bleaching and pitch problems, Svensk Papperstidn. 94(6), 32.

Smith R. M., and Martell A. E. (1989): "Critical Stability Constants," Vol. 6, Plenum Press, New York.

Smoluchowski, M. von (1903): Contribution to the theory of electro-osmosis and some related phenomena, Bull. Int. Acad. Sci. Cracovie 3, 182.

Smoluchowski, M. von (1918): Investigation of a mathematical theory for the coagulation of colloidal suspensions, Z. Physikalische Chemie, 92(2), 129.

Snyder, B. A., and Berg, J. C. (1994): Liquid bridge agglomeration: A fundamental approach to toner deinking, Tappi J. 77(5), 79.

Song, Z, and Ford, P. (2004): Use of a water-soluble crosslinked cationic polymer for controlling deposition of pitch and stickies in papermaking, US Pat. Off. Publ. 200405226676 .

Stenkamp, V. S., and Berg, J. C. (1997): The role of long tails in steric stabilization and hydrodynamic layer thickness, Langmuir, 13(14), 3827.

Stitt, J. B. (1997): Slime and deposit control: Alkaline challenge, PIMA's North American Papermaker, 79(9), 54.

Stitt, J. B. (1998): Charge control helps tissue producers achieve quality, productivity benefits, Pulp Paper, 72(5), 109.

Strazdins, E. (1989): Theoretical and practical aspects of alum use in papermaking, Nord. Pulp Paper Res. J. 4(2), 128.

Stubenrauch, C., Rojas, O. J., Schlarmann, J., and Claesson, P. M. (2004a): Interactions between nonpolar surfaces coated with the nonionic surfactant hexaoxyethylene dodecyl ether $\mathrm{C} 12 \mathrm{E} 6$ and the origin of surface charges at the air/water interface, Langmuir, 20(12), 4977.

Stubenrauch, C., Schlarmann, J., Rojas, 0. J., and Claesson, P. M. (2004b): Comparison between interaction forces at air/liquid and solid/liquid interfaces in the presence of non-ionic surfactants, Tenside, Surfactants, Detergents, 41(4), 174.

Sundberg, A., Ekman, R., Holmbom, B., and Grönfors, H. (1994a): Interactions of cationic polymers with components in thermomechanical pulp suspensions, Paperi Puu, 76(9), 593.

Sundberg, K. E., Thornton, J., Pettersson, C., Holmbom, B., and Ekman, R. (1994b): Calcium-Induced Aggregation of Dissolved and Colloidal Substances in Mechanical Pulp Suspensions, J. Pulp Paper Sci. 20, J317.

Swanson, J. W., and Cordingly, R. H. (1956): Surface chemical studies on pitch, Tappi, 39(10), 684.

Swerin, A., and Ödberg, L. (1997): Some aspects of retention aids, in "The Fundamentals of Papermaking Materials," Edited C. F. Baker, Pira Intl., Leatherhead, UK, 265.

Tam Doo, P. A., Kerekes, R. J., and Pelton, R. H. (1984): Estimates of maximum hydrodynamic shear stresses on fiber surfaces in papermaking, J. Pulp Paper Sci. 10(7), J80.

Urbanski, J. (1990): Teflon covers solve starch buildup problem on Flambeau Dryer Cylinders, Pulp Paper, 64(2), 89.
Vähäsalo, L., and Holmbom, B. (2005): Influence of latex properties on the formation of white pitch, Tappi J. 4(5), 27.

Van de Steeg, H. G. M., Cohen Stuart, M. A., de Kaizer, A., and Bijsterbosch, B. (1992): Polyelectrolyte adsorption - A subtle balance of forces, Langmuir, $8(10), 2538$.

Van de Ven, T. G. M., and Mason, S. G. (1981): Comparison of hydrodynamic and colloidal forces in paper machine headboxes, Tappi, 64(9), 171.

Van Duijvenbode, R. C., and Koper, G. J. M. (2001): Effect of particle size on the sticking probability, J. Colloid Interface Sci. 239(2), 581.

Van Haute, E. (2003): Enzymes and biodispersants as highly performing alternatives to conventional deposit control programs on paper machines, Chimica Oggi-Chemistry Today, 21(12), 48.

Van Olphen, H. (1991): "Clay Colloid Chemistry," 2nd Ed., Krieger Publ. Co., Malabar, FL.

Venditti, R. A., Lucas, B. E., and Jameel, H. (2004): Extrusion and folding models for the passage of pressure sensitive adhesive materials through slotted screening devices in paper recycling, Proc. 7th Research Forum on Recycling, September 27-29, 2004, Quebec City, Canada..

Venditti, R. A., Zhang, C., Buchanan, C. G., Gilbert, R. D., Abubakr, S., and Bormett, D. (1998): Deposition analysis of pressure sensitive adhesives, Proc. Recycling Symp., 475, TAPPI Press, Atlanta.

Venditti, R. A., Zhang, C., and Gilbert, R. D. (2000): Effect of release liner on paper recycling and pressure sensitive adhesives, Proc. Paper Recycling Conf., 579, TAPPI Press, Atlanta.

Vercoe, D., Stack, K., Blackman, A., and Richardson, D. (2005): A multicomponent insight into the interactions leading to wood pitch deposition, Appita J. 58(3), 208.

Verwey, E. J. W., and Overbeek, J. T. G. (1948): "Theory of the Stability of Lyophobic Colloids," Elsevier, New York.

Voue, M., Valignat, M. P., Oshanin, G., Cazabat, A. M., and De Coninck, J. (1998): Dynamics of spreading of liquid microdroplets on substrates of increasing surface energies, Langmuir, 14(20), 5951.

Wade, D. E. (1987): Sticky pacification with synthetic pulps, Proc. Pulping Conf., Book 3, 579, TAPPI Press, Atlanta.

Wågberg, L. (2000): Polyelectrolyte adsorption onto cellulose fibers - A review, Nord. Pulp Paper Res. J. 15(5), 586.

Wang, X. H. (2002): Surface and colloid chemistry of papermaking, in "Encyclopedia of Surface and Colloid Science," Edited P. Somasundaran, Marcel Dekker, New York.

Welkener, U., and Hassler, T. (1994): Pitch control, US pat. 5,300,194.

Whiting, P. L. (1997): Contaminant control on a high speed paper machine, Proc. Engineering and Papermakers Conf., 661, TAPPI Press, Atlanta.

Williams, G. R. (1987): Physical chemistry of the absorption of talc, clay, and other additives on the surface of sticky contaminants, Proc. Pulping Conf., Book 3: 563, TAPPI Press, Atlanta.

Winter, L., Lorenãak, P., and Lorz, R. (1992): New techniques for controlling pitch problems - Optimum application of various polymers in TMP furnishes, Proc. 1992 Pan-Pacific Pulp Paper Technol. Conf., Part B, paper 13, 99, Japan TAPPI.

Woolery, R. G. (1965): Effects of chrysotile asbestos additions to cellulosic paper, Tappi, 48(8), 92A.

Zeng, J., Venditti, R. A., and Olf, H. G. (2001): Role of contact angle in 1-octadecanol agglomeration of electrostatic toners, J. Pulp Paper Sci. 27(3), 98.

Zeng, J., Venditti, R. A., and Olf, H. G. (1999): Toner-specific effect in 1-octadecanol agglomeration of electrostatic toners, Prog. Paper Recycling 9(1), 30.

Manuscript received September 4, 2005 Accepted December, 2005 